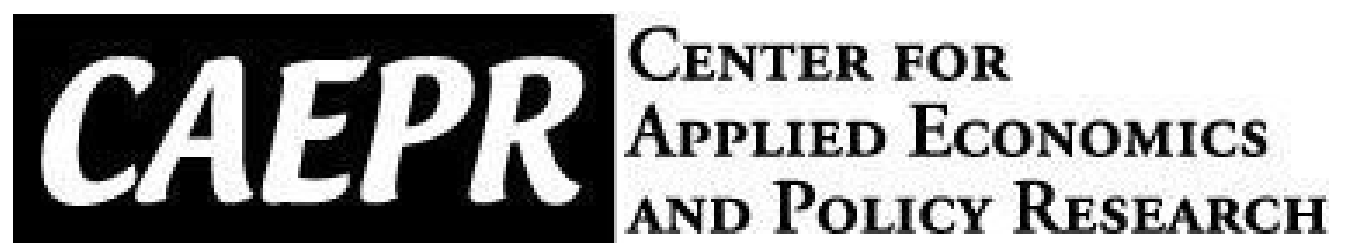

\author{
CAEPR \\ Working Paper \\ \#2020-002
}

Do Larger Importing Firms Face Lower Freight Rates?

\author{
Adina Ardelean \\ Santa Clara University \\ Volodymyr Lugovskyy \\ Indiana University \\ First Draft: July 11, 2016 \\ Current Draft: January \\ 29, 2020
}

This paper can be downloaded without charge from the Social Science Research

Network electronic library at https://papers.ssrn.com/sol3/abstract_id=3529520

The Center for Applied Economics and Policy Research resides in the Department of Economics at Indiana University Bloomington. CAEPR can be found on the Internet at: http://www.indiana.edu/ caepr. CAEPR can be reached via email at caepr@indiana.edu or via phone at 812-855-4050.

(C)2019 by Adina Ardelean and Volodymyr Lugouskyy. All rights reserved. Short sections of text, not to exceed two paragraphs, may be quoted without explicit permission provided that full credit, including (c) notice, is given to the source. 


\title{
Do Larger Importing Firms Face Lower Freight Rates? *
}

\author{
Adina Ardelean ${ }^{\dagger}$ \\ Santa Clara University
}

\author{
Volodymyr Lugovskyy ${ }^{\ddagger}$ \\ Indiana University
}

First Draft: July 11, 2016

Current Draft: January 29, 2020

\begin{abstract}
This paper documents that, even within a narrowly defined product and port-to-port route, the maritime international freight rates are lower for larger importing firms. Even after controlling for shipment sizes, the 90th-percentile importing firm faces a $20 \%$ lower freight rate and, as a result, a $1.8 \%$ lower delivered price for a given product and route than the 10th-percentile firm. The firm size matters only in the presence of some degree of competition among shippersmonopoly shippers charge a higher, but symmetric freight rates across all firms. These results are consistent with our theoretical predictions and are robust to multiple robustness checks, including controlling for the size of an exporting firm. We further argue that asymmetries in access to imports affect input prices, TFP estimation, and magnify the extent of firm size heterogeneity.
\end{abstract}

Keywords: Freight Rates, Firm Size Advantage, Maritime Shipping

${ }^{*}$ We thank Enghin Atalay, John Asker, Andy Bernard, Paola Boel, Eric Bond, David Hummels, Anna Ignatenko, Michael Kevane, Ahmad Lashkaripour, Goncalo Pina, Peter Schott, Alexandre Skiba, Asha Sundaram, Judit Temesvary, and participations at the 2018 Australasian Trade Workshop in Auckland, New Zealand, 2016 Southern Economic Association Meetings in Washington D.C., 2017 Midwest International Trade Meetings, 2017 Western Economic Association Meetings in San Diego, Yellow Pad Seminar at Santa Clara University, and Trade Talk participants at Indiana University for helpful comments on this paper. All remaining errors are ours.

${ }^{\dagger}$ Department of Economics, Santa Clara University, 500 El Camino Real, Santa Clara, CA 95053-0385, atardelean@scu.edu, Phone: 408-554-6968

${ }^{\ddagger}$ Department of Economics, Indiana University, 100 S. Woodlawn, Bloomington, IN 47405-7104, vlugovsk@indiana.edu 


\section{Introduction}

Existing research shows that transport cost is an important determinant of international trade patterns, volume, and composition. Numerous studies documented that freight rates vary significantly across routes. Are rates symmetric within a route? All major models of international trade assume that they are. Within-route transport costs are assumed to be symmetric 1 whether they are modeled as ad-valorem ('iceberg') or specific ${ }^{2}$ implying symmetric access to imports within a country - a critical assumption for deriving equilibrium conditions and evaluating welfare gains from trade.

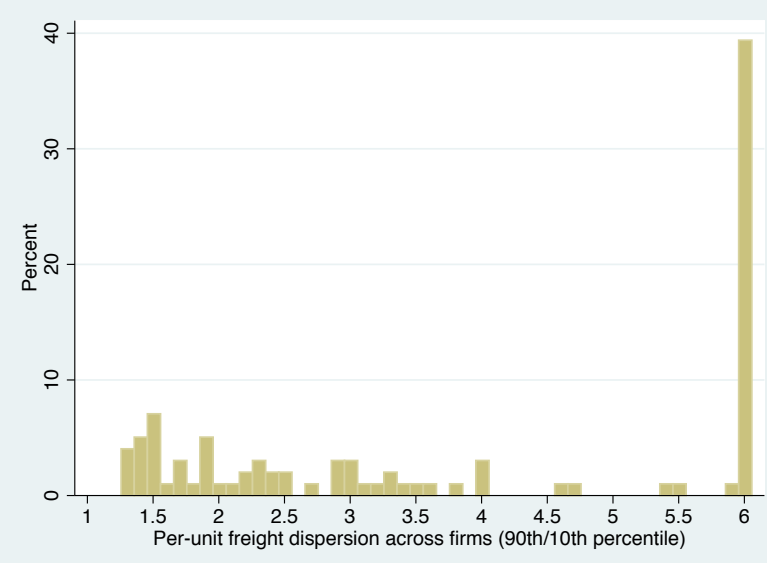

(a) Dispersion in the Specific Transport Costs

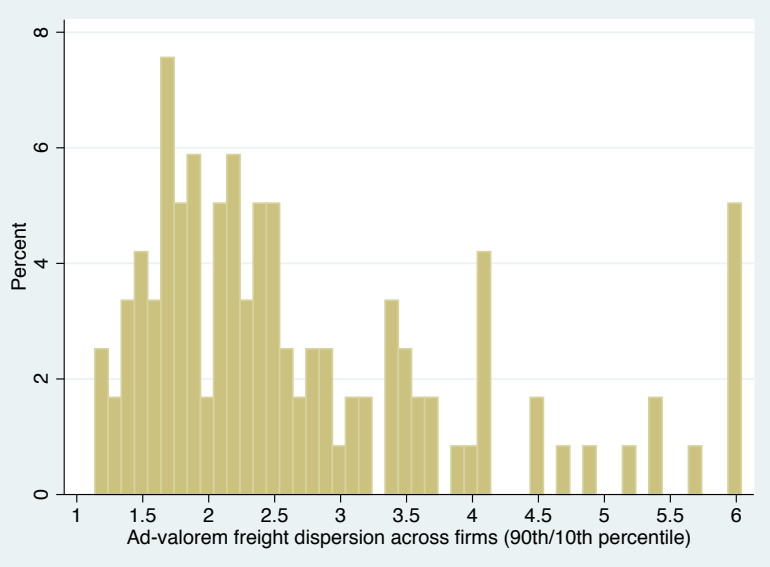

(b) Dispersion in the Iceberg Transport Costs

Notes: Products are defined at a 8-digit Harmonized System level. For readability, all values above 6 are set to 6.

Figure 1: The distribution of the within product-route-shipper 90th-to-10th percentile freight rate ratio, Chilean maritime imports, 2007.

A simple look at the data, however, shows a significant variation in the port-to-port freight rates within narrowly defined products. For example, the maritime freight rate for men's cotton shirts from Shanghai, China, to San Antonio, Chile, varies up to 800\%. Across all Chilean maritime imports of non-bulk commodities, the within product-route-shipper high-to-low freight rate ratio is

${ }^{1}$ Exceptions are the models with asymmetry in transportation costs due to either different modes of transportation (e.g. Hummels and Schaur, 2010) or internal distance of imports (e.g., Atkin and Donaldson, 2015, Ramondo et al., 2016 Lugovskyy and Skiba, 2019). Even in these models, however, the port-to-port transportation costs for a given product are symmetric.

${ }^{2}$ Vast majority of trade models assume transportation cost to be ad-valorem (e.g., Krugman, 1980, Eaton and Kortum, 2002 Melitz, 2003, Arkolakis et al., 2012). The few exceptions are, among others, Hummels and Skiba (2004); Feenstra and Romalis (2014); Irarrazabal et al. (2015), which consider specific transportation costs. In all these models, however, transportation costs are symmetric within a product-route pair. 
greater than two for the majority of product-routes (see Figure 1).

Historically, a prominent example of within-route asymmetry in transportation costs dates back to 1868, when Standard Oil used its monopsony power to receive the railroad rebates (Reksulak and Shughart, 2011). In the modern international maritime shipping, however, the monopsony power is rare as the observed concentration of buyers is low ${ }^{3}$ Instead, Holmes and Singer (2018) and our paper argue that the variation in freight rates is more likely to be caused by scale effects at firm and shipment levels.

Our focus is on the within-route maritime freight rate for non-bulk products ${ }^{4}$ The key to our empirical part is an extremely detailed transaction-level Chilean Imports dataset for two time periods, 2007-2009 and 2014-2015. We start by documenting two important facts. First, by observing the International Chamber of Commerce's International Commerce Terms (Incoterms), we document that, contrary to a common belief in trade models (e.g., Krugman, 1980, Melitz, 2003), it is importing rather than exporting firms, which tend to arrange the international shipping 5 Second, we show that freight rates are negatively correlated with the size of importing firms.

Motivated by these findings, we propose a model of a two-sided market of shipping with shippers as sellers and importing firms as buyers and link the variation in freight rates across firms to the economies of scale experienced by shippers when dealing with larger buyers. These economies of scale arise due to the contract-specific fixed cost, where contract size increases in the buyer's annual demand for shipping. Another critical assumption of the model is that the demand for transportation stems from import demand, and thus, up to some point, is freight rate invariant. We predict the freight rate to decrease in the firm size, but only in the presence of competition among shippers - a monopolist charges a higher but symmetric freight rate to all importing firms.

A simple intuition behind our model is that the average cost of transportation decreases in the firm size. In the presence of competition, shippers adjust their pricing accordingly, charging lower prices to larger firms. A monopolist shipper, however, is bound only by the outside opportunity

\footnotetext{
${ }^{3}$ As we show in Table 1 , the average the Herfindahl-Hirschman concentration index of buyers within a given route of Chilean non-bulk maritime imports is only 0.16 out of 1 .

${ }^{4}$ Maritime shipments represent two-thirds of Chilean imports by value and over $90 \%$ by weight.

${ }^{5}$ This pattern is consistent with the evidence documented by (Teshome, 2018) fo Colombian firms. Other models, in which importing firms play a pro-active role in finding foreign suppliers, and thus more likely incurring the international transportation cost, include Rauch and Watson (2003) and Antra s et al. (2017).
} 
freight rate (e.g., indirect route) and thus charges a uniform freight rate - equal to the outside opportunity - to all firms.

Guided by our theoretical predictions, we relate the within-product-route freight rate to variation in importing firm size and to its interaction with a monopoly shipper dummy variable. The transaction-level freight rates are measured net of insurance at a highly disaggregated 8-digit Harmonized System (HS) product level, the routes are defined by a port of loading and port of unloading, and the shipments are defined by a Clearance ID number. We use route-product-year-month fixed effects to control for the various cost shifters common to a given route-product-time triplet and the shipper fixed effects to control for the shipper-specific characteristics. We document a substantial freight rate measurement bias in multi-product shipments and therefore restrict our sample to single-product shipments ${ }^{6}$ In line with the existing literature on the determinant of the freight rate, we also control for the f.o.b. product price, shipment size, and weight per unit.

To control for potential endogeneity between freight rates and f.o.b. prices (highlighted by Hummels and Skiba, 2004), we utilize the fact that, for a significant portion of transactions, the country of origin is different from the country of loading. As a result, we can use the income per capita of the country of origin as a unique, transaction-level instrument of the f.o.b. price.

Our data confirm the model predictions: freight rate decreases in the importing firm size if a route is served by several shippers, but not in the routes with a monopoly shipper. On 'nonmonopoly' routes, the estimated firm size elasticity of the freight rate equals 0.04 , with the resulting difference between the 90 th-percentile and 10 th percentile importers of $20 \%$. The freight rate also decreases in the shipment size which further contributes to the freight rate dispersion. Specifically, if we take into account that larger firms import heavier shipments, the 90th-to-10th percentile firm freight rate dispersion further increases to $50 \% .7$

Our results are robust to controlling for the size of the matched exporting firms. We show this by leveraging a similar Colombian imports dataset, in which we observe the identities of both importing

\footnotetext{
${ }^{6}$ In multi-product shipments, the freight rates are assigned across products based on their fob values, thus generating a pronounced ad-valorem measurement bias. Our firm-size results are robust to using multi-product shipments.

${ }^{7}$ If we further consider that larger firms tend to import more expensive goods, the 90th-to-10th percentile firm ad-valorem freight rate dispersion reaches $91 \%$, meaning that the 90 th percentile firm faces 11 times lower ad-valorem freight rate than the 10 th percentile firm.
} 
and exporting firms 8 We find the freight rate to be several times more sensitive to the importer than to the exporter size, which is consistent with Incoterms evidence of importing firms arranging most of the international transportation. Our results are also robust to various definitions of the firm size (e.g., by value, weight, and lagged value). Finally, while the price coefficient becomes highly biased, the firm-size results remain virtually unchanged if we include multi-product shipments.

Our findings have broader implications. Using our data and estimation results, we infer that the asymmetry in freight rates lowers the delivered price of the same product on the same route by $1.8 \%$ for the 90 th percentile firm compared to the 10th percentile firm. This gap increases to $5.5 \%$ if we take into account shipment sizes. This asymmetry in access to imports across firms of different sizes contributes to differences in unit production costs and can bias the TFP estimation when using expenditures on inputs. It also contributes to a larger firm size dispersion.

The remainder of the paper is organized as follows: Section 2 describes our contribution to the existing literature, Section 3 introduces the data, Section 4 presents a model, Section 5 describes the empirical methodology, presents the results, including the robustness checks. Section 6 discusses broader implications of our findings, Section 7 concludes.

\section{Contributions to the Literature}

This paper contributes to several important literatures. First, we contribute to the literature on firm heterogeneity and trade. While the primary reason for firm heterogeneity does not need to be trade-related 9 , trade may contribute to the asymmetry across firms through various channels. For example, exporting firms may become relatively larger through access to foreign markets (Melitz, 2003), while importing firms may become more efficient through buying foreign intermediates at lower (quality-adjusted) prices (Amiti and Konings, 2007, Kasahara and Rodrigue, 2008, Topalova and Khandelwal, 2011; Halpern et al., 2015). Larger firms have also been shown to adjust better to trade shocks, such as exchange rate appreciation or restrictive product standards (Berman et al.

\footnotetext{
${ }^{8}$ The disadvantage of Colombian dataset, though, is that we do not observe port-to-port routes but only countryto-country routes. In order to increase the accuracy of measuring the exact port-to-port freight rates, we chose to use Chilean imports as our main sample.

${ }^{9}$ E.g., larger firms tend to be firms with better management (Bloom et al. 2010)
} 
2012, Fontagne et al., 2015). The growing literature on buyer power in international trade (e.g., Raff and Schmitt, 2009; Grossi et al., 2019, Morlacco, 2019) shows that larger importing firms, ceteris paribus, import inputs at lower prices. Understanding which firms gain more from trade is critical for the analysis of redistributive effects of trade and trade policies (Hallak and Levinsohn, 2004, Bernard and Dhingra, 2019). We contribute to this literature by showing that there is another, previously unexplored channel through which trade further increases the asymmetry between large and small firms: large firms face lower freight rates and thus import inputs at lower delivered prices - even when factory prices are symmetric across firms.

Second, we contribute to an extensive exploration of the price dispersion and market structure by the industrial organization literature. When sellers have market power 10 the textbook theory predicts greater price dispersion in more concentrated markets (Schmalensee and Willig, 1989), ${ }^{11}$ When considering market concentration and the extent of price dispersion under third-degree price discrimination, however, Borenstein (1985) and Holmes (1989) provided a formal discussion of both positive and negative correlations. Empirically, in the passenger airline industry, Borenstein and Rose (1994) showed that price dispersion increased with the competition. In contrast, Stavins (2001) and Gerardi and Shapiro (2009) claimed the opposite - the latter attributed the Borenstein and Rose (1994)'s result to the omitted variables bias and invalid instrument. In the markets of Yellow Pages advertising, Busse and Rysman (2005) found that concentration decreases price dispersion. We contribute to this literature by documenting the negative relation between the shippers' concentration and the extent of freight rate dispersion.

Third, this paper is closely related to the extensive literature on the determinants and functional form of maritime international transportation costs. Previous literature has examined the dependence of freight rates on the port efficiency (Blonigen and Wilson, 2008), competition among and size of shippers (Hummels et al., 2009, Asturias, 2019), unit values (Hummels and Skiba, 2004; Lashkaripour, 2019), tariffs and total value of trade (Hummels et al., 2009; Asturias, 2019), containerization (Coşar and Demir, 2018), geography and networks (Brancaccio et al., 2017), and

\footnotetext{
${ }^{10}$ As discussed above, the price dispersion in our setting is unlikely to arise due to the market power of buyers (monopsony power) since the average buyer's concentration on a route is low: HHI=0.16 (Table 1).

${ }^{11}$ See Stole (2007) for a literature review on the theoretical models describing different types of price discrimination in imperfect markets.
} 
backhaul problem (Ishikawa and Tarui, 2018; Wong, 2018). This literature studies the effect of all these factors on the average freight rate on a given route. We contribute to this literature by showing that there is a pronounced freight rate dispersion within a route, with larger firms facing lower freight rates.

Two other papers which examine the within-route differences in freight rates are by Holmes and Singer (2018) and Ignatenko (2019). There are several similarities between Holmes and Singer (2018) and our research. Both papers emphasize savings by larger importing firms due to scale effects. Holmes and Singer (2018) attribute scale effects to indivisibilities when, due to the fixed container size, shipment costs are not proportional to the shipment size - as they put it, "dividing a shipment in half does not divide the cost in half." Their data advantage is in observing container types and sizes and whether a container is filled to full capacity. They establish that larger companies pack shipments fuller than smaller companies, which is in line with our finding that firm size matters even beyond the shipment size. They do not, however, observe the unit values of the imported goods at the shipment level 12 They implicitly assume that freight rates do not depend on the unit values of the goods. While in some of our 'weight' specifications, the price coefficient is indeed statistically insignificant, in our 'value' specifications, as well as in Hummels et al. (2009), unit value serves as the most critical determinant of the maritime freight rate 13 Another crucial distinction of our paper is in establishing that the extent of freight rate dispersion depends on the market structure of shippers and disappears under a monopoly shipper.

Using Paraguay data on road and river transportation, Ignatenko (2019) finds similar effects of the firm size and shipment size on the freight rate faced by both importing and exporting firms. Our results are complementary in several ways: (i) we show these results for international maritime transportation; (ii) we use much more detailed fixed effects (route-product (at HS8 level)-yearmonth and shipper fixed effects); (iii) using the Incoterms variable, we establish that importing firms are much more likely to arrange for international shipping; and (iv) we show that the firm

\footnotetext{
${ }^{12}$ For some shipments they can match the freight rates with the year-average c.i.f. unit values of a good coming from a given country. For some of their exercises, they assume the freight cost of delivering the container to a U.S. port to be $8 \%$ of the total wholesale price (including freight to a U.S. port).

${ }^{13}$ Their assumption might be less restricting for the U.S. imports for which Hummels and Skiba (2004) estimated the price elasticity of the freight rate to be only 0.11 - much lower than when including the Latin American countries in the sample (0.61).
} 
size effect disappears on the routes with monopoly shippers.

\section{Data Patterns}

We use Chilean Customs transaction-level import data for 2007-2009 and 2014-2015, obtained from Datamyne ${ }^{14}$ For each import transaction, the data include the identity of the Chilean importing firm, date, the Harmonized System 8-digit product category (HS8), f.o.b. ("free on board") and c.i.f. ("customs, insurance, and freight") values of products in U.S. dollars, quantity, unit of measurement (of quantity), freight in U.S. dollars, insurance in U.S. dollars, port of loading (henceforth PoL), port of unloading (henceforth PoU), country of origin, shipment composition, mode of transportation, shipper's or logistics firm's identity, and shipment gross weight 15

This level of detail is unique. For comparison, the U.S. Census Imports data are aggregated at product-month-(district of entry)-(exporting country) level and report freight combined with insurance ${ }^{16}$ while the Latin American International Transport Database reports the freight rate at country-product-year level 17 Other direct measures of transportation costs are sourced from shipping quotes and freight rates for a standard container (e.g., Limao and Venables, 2001; Hummels, 2007; Wong, 2018; Asturias, 2019) as well as contract prices per ship per day for bulk commodities (Brancaccio et al. 2017). The more detailed information provided in our data permits us a closer examination of the nature of international shipping costs, which represent a significant part of international trade costs (Clark et al., 2004, Anderson and van Wincoop, 2004).

For 2014-2015, we also observe the International Chamber of Commerce's International Commerce Terms (Incoterms), which define exporter's and importer's responsibilities during the delivery process. We calculated that, for the maritime non-bulk shipments, which are the focus of our research, importers were responsible for arranging international shipping twice more often than

\footnotetext{
${ }^{14}$ Datamyne is a company that specializes in documenting import and export transactions in Americas. For more detail, please see www.datamyne.com.

${ }^{15}$ Gross weight is the weight of each shipment identified by the clearance id, including the containership. One shipment can contain multiple transactions - one for each product in the shipment.

${ }^{16}$ The Army Corps of Engineers (A.C.E.) used Census Imports data to construct port-to-port variant of U.S. imports at somewhat higher product-level aggregation (HS6 instead of HS10), but these data are not available past 2009 (Blonigen and Wilson 2018, Chapter 16, Footnote 7).

${ }^{17}$ It is sourced from the Economic Commission for Latin America and the Caribbean ECLAC. See Hummels and Skiba (2004); Hummels et al. (2009) for estimating the functional form of transportation cost using this dataset.
} 
exporters (58\% vs 29\%). These findings are consistent with those of Teshome (2018) for Colombian exports and show that importers are much more likely to negotiate international freight rates than exporters ${ }^{18}$ Zooming in on importers, we proxy their bargaining power by the value or weight of their annual imports on all routes from an exporting country ${ }^{19}$

We trim and aggregate the data along several dimensions. First, we found that, within a shipment (defined by Clearance ID), the freight cost for each product is assigned strictly proportionally to its f.o.b. value. Since transportation payment is negotiated per shipment rather than per product, this is the most straightforward method to calculate the tariff base for each product ${ }^{20}$ While convenient, this method generates a pro-iceberg bias in multi-product shipments - overstating the freight rate for more expensive products and understating it for cheaper products. To eliminate this bias, we restrict our sample to single-product (HS8) shipments ${ }^{21}$ Second, we exclude import transactions in bulk commodities ${ }^{22}$ because bulk and containerized shipping operations are very different (Brancaccio et al., 2017). Third, we exclude the top and bottom $1 \%$ of firms based on their total annual imports. We also screen the import dataset to exclude routes with less than ten importing firms per year to ensure that there is a sensible set of firms importing on a given route every year and we eliminate the routes between two Chilean ports.

Table 1 reports various summary statistics averaged across routes for 2007-2009 and 2014-2015. We observe that routes differ significantly in the value of imports with a heavy concentration on a few routes ${ }^{24}$ The average firm HHI and the average number of firms on a given route show that routes are not dominated by just a few importing firms. On the average route, the number of shippers is significantly smaller than the number of importing firms, and the average shipper HHI

\footnotetext{
${ }^{18}$ In our data, Incoterms C.F.R. (12.2\% of all shipments), C.I.F. (16.6\%), and DDP (0.1\%) denote that exporter's responsibility for arranging the international shipping; EXW (11.2\%), F.A.S. (0.2\%), F.O.B. (47.0\%) denote importer's responsibility; missing Incoterms (11\%); and we are not sure how to interpret the FOB-FRONTERA (2\%). Teshome (2018) reported $80 \%$ of shipments being arranged by importers and $15 \%$ - by exporters ( $5 \%$ - missing Incoterms).

${ }^{19}$ The firm size is calculated net of the current shipment to avoid the endogeneity between the freight rate and size.

${ }^{20}$ In Chile, as in many other countries, excluding the Commonwealth of Nations and the U.S.A., tariff base for imports includes transportation costs (Feenstra and Romalis, 2014).

${ }^{21}$ For comparison, we also report the estimation results based on the full sample (see Table 4 .

${ }^{22}$ E.g., grains, mineral fuels, iron ore, chemicals/fertilizers, wood, and sand. As a robustness check, we provide results for the sample that includes all commodities (see Table 9 .

${ }^{23}$ We will use variation across firms on a given route in our specification in section 4.2 . and we need to ensure that we have sufficient variation to identify the coefficients of interest. Results are similar if we vary this threshold.

${ }^{24}$ In 2007, the top five routes (Manzanillo-Valparaiso, Hong Kong-Valparaiso, Hamburg-Valparaiso, HoustonAntofagasta, and Busan-Valparaiso) accounted for about $25 \%$ of Chilean imports.
} 
Table 1: Route-Specific Summary Statistics of Maritime Imports

\begin{tabular}{l|c|cc}
\hline \hline Years & \multicolumn{2}{|c}{$2007-2009$} & \multicolumn{2}{c}{$2014-2015$} \\
\hline No. of routes & 260 & 260 & \\
\hline Average trade, mil. USD (Sd. Dev) & $49.66 \quad(93.99)$ & 56.05 & $(113.39)$ \\
Median trade, mil. USD & 10.47 & 14.75 & \\
Average no. of firms & 209 & 206 & \\
Average firm-HHI & 0.16 & 0.16 \\
Average no. of shippers & 6 & 6 \\
Average shipper-HHI & 0.52 & 0.49 \\
Average no. of countries of origin & 12 & 12 \\
Average no. of products & 181 & 157 \\
\hline \hline
\end{tabular}

is three times higher than the average firm HHI. Products shipped on an average route originate from 12 countries, which is important for our estimation, as we instrument the prices with the GDP per capita of the country of origin (obtained from Penn World Tables version 9.0 (Feensta et al. 2015)). These facts are similar across the years.

Table 2 reports various summary statistics averaged across firms for 2007-2009 and 2014-2015. During the period 2007-2009, the average Chilean firm-level imports amounted to 1.07 million USD (1.83 thousand tons) organized in 18 shipments across 4 routes from 3 exporting countries. The average number of imported HS8 products per firm was 5, and the average number of shippers used by a firm was 3 . In both periods, the distribution of import values and weight across firms is skewed to the right. That is, there are many small Chilean firms and a small number of large importing firms. The number of importing firms has increased between 2007-2009 and 2014-2015, with each firm importing, on average, less and in fewer shipments annually.

Figure 2 shows the non-parametrically estimated 25 density distributions of the logarithm of firm's annual import value (left panel) and the logarithm of firm's annual import weight (right panel). The distribution of the logarithm of firm size measured in US dollars is right-skewed. In contrast, the distribution of firm size measured in kilograms is more symmetric, close to a log-normal distribution.

\footnotetext{
${ }^{25}$ We use a kernel density smoother.
} 
Table 2: Firm-Specific Summary Statistics of Maritime Trade

\begin{tabular}{l|cc|cc}
\hline \hline Years & \multicolumn{2}{|c}{$2007-2009$} & \multicolumn{2}{c}{$2014-2015$} \\
No. of firms & \multicolumn{2}{|c}{15,067} & \multicolumn{2}{c}{17,365} \\
\hline Average firm's imports, mil. USD (Sd. Dev.) & 1.07 & $(6.77)$ & 1.03 & $(7.19)$ \\
Median firm's imports, mil. USD & 0.08 & & 0.07 & \\
Average firm's imports, mil. kg (Sd. Dev.) & 1.83 & $(32.28)$ & 0.94 & $(10.85)$ \\
Median firm's imports, mil. kg & 0.03 & & 0.03 & \\
Average no. of shipments (St. Dev) & 18 & $(93)$ & 13 & $(74)$ \\
Average shipment, mil.USD (St. Dev) & 0.05 & $(0.33)$ & 0.05 & $(0.15)$ \\
Average shipment, mil. kg (St. Dev) & 0.02 & $(0.21)$ & 0.01 & $(0.07)$ \\
Average no. of products (St. Dev) & 5 & $(12)$ & 4 & $(9)$ \\
Average no. of routes (St. Dev) & 4 & $(5)$ & 3 & $(5)$ \\
Average no. of exporter countries (St. Dev) & 3 & $(3)$ & 3 & $(3)$ \\
Average no. of shippers (St. Dev.) & 3 & $(3)$ & 3 & $(2)$ \\
\hline \hline
\end{tabular}

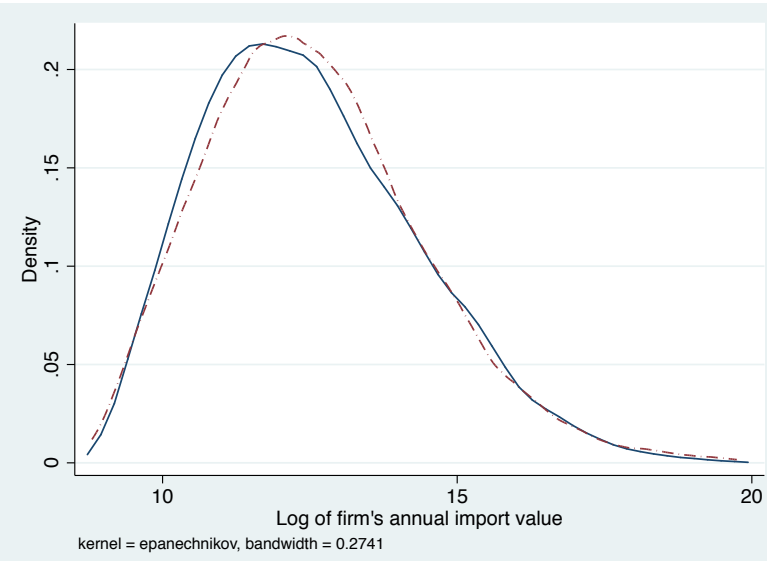

(a) Value

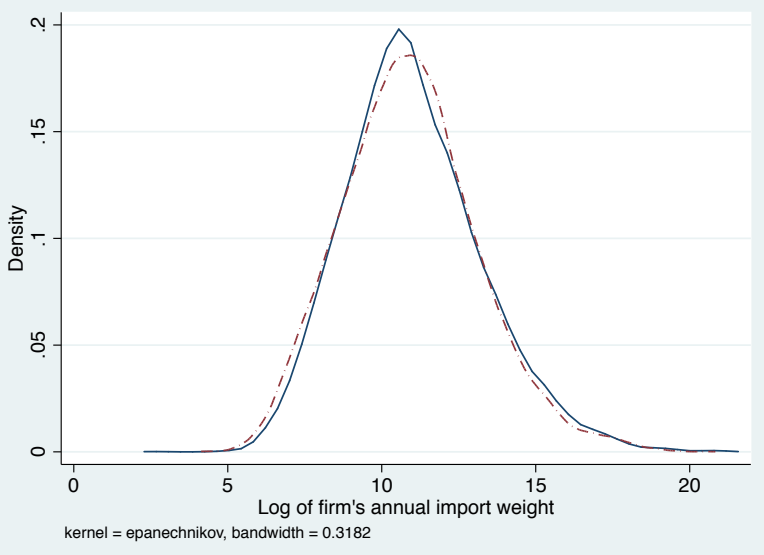

(b) Weight

Figure 2: Firm Size Distribution in 2007 (solid line) and in 2015 (dashed line).

To better understand the effects of firm size, we run a set of ordinary least square regressions:

$$
\ln Y_{f t}=\alpha_{1}+\alpha_{2} X_{f t}+\alpha_{t}+\epsilon_{f t},
$$

where, for firm $f$ in year $t, Y_{f t}$ is taking values of the (i) average shipment measured by value and by weight; (ii) number of shipments, HS 8-digit products, routes, and shippers; and (iii) average specific and ad-valorem freight rates (mean-differenced by route-product-year). We relate each dependent variable, $Y_{f t}$, to the $\log$ of the firm's annual import value or weight, $X_{f t}$. We include year fixed effects, $\alpha_{t}$, to control for differences in firms' trade characteristics across the years. 
Table 3: Firm-Level Heterogeneity in Trading Activity

\begin{tabular}{l|cc|cc}
\hline \hline Dependent Variable: & \multicolumn{3}{|c}{ Log of Firm's } & Annual Imports \\
\hline & \multicolumn{2}{|c}{$2007-2009$} & \multicolumn{2}{c}{$2014-2015$} \\
\hline Log of Specific Freight & Value & Weight & Value & Weight \\
Log of Ad-valorem Freight & $-0.17^{* * *}$ & $-0.26^{* * *}$ & $-0.21^{* *}$ & $-0.35^{* * *}$ \\
Log of Average Shipment & $-0.22^{* * *}$ & $-0.07^{* * *}$ & $-0.25^{* * *}$ & $-0.13^{* * *}$ \\
Log of Number of Shipments & $0.35^{* * *}$ & $0.48^{* * *}$ & $0.35^{* * *}$ & $0.50^{* * *}$ \\
Log of Number of HS8 Products & $0.58^{* * *}$ & $0.44^{* * *}$ & $0.51^{* * *}$ & $0.42^{* * *}$ \\
Log of Number of Routes & $0.36^{* * *}$ & $0.26^{* * *}$ & $0.31^{* * *}$ & $0.23^{* * *}$ \\
Log of Number of Shippers & $0.35^{* * *}$ & $0.27^{* * *}$ & $0.32^{* * *}$ & $0.25^{* * *}$ \\
\hline \hline
\end{tabular}

Notes: 1. Data are aggregated to a firm-year level.

2. Specific (i.e., freight charges per $\mathrm{kg}$ ) and ad-valorem freight rates are mean-differenced by HS8 product, route, and year before taking the simple average by the firm-year.

3. All results are from ordinary least squares regressions of firm's characteristics in column (1) on the total value of firm's imports in the same year in column (2) and (4) and the total weight of firm's imports in the same year in column (3) and (5). Average shipment is measured in million US dollars when regressed on the value of firm's annual imports and in million kilograms when regressed on the weight of firm's annual imports

4. All regressions include a constant term and year fixed effects.

5. Robust standard errors. $* * *, * * *$ significant at 10,5 , and 1 percent, respectively.

Table 3 reports the estimated within-year conditional correlation between $Y_{f t}$ and $X_{f t}, \alpha_{2}$. The estimates show that larger importers are different from smaller importers: they import more shipments, that are larger in value and weight, more products, use more routes and more shippers, and face lower (both specific and ad-valorem) freight rates.

\section{Model}

Motivated by the data patterns discussed above, we provide a simple model of a two-sided market with shippers as sellers and importing firms as buyers of transpiration services. Consider a market of international maritime shipping on a route $r=1,2, \ldots, n_{r}$. The supply side consists of $c=1,2,3, \ldots, n_{c}$ carriers (henceforth, shippers), whereas the demand side is represented by $i=1,2,3, \ldots, n_{i}$ importing firms in Home. In what follows, we will focus on route $r$ in year $y$, and, for brevity, we will drop subscripts $r$ and $y$. We start by listing the key assumptions of the model.

Assumption 1 The marginal cost of shipping $\beta_{c t}$ is constant for a given shipper $c$ in time period

t. The information about the exact value of $\beta_{c t}$ is private. In every period $t$, each shipper's $\beta_{c t}$ is independently and identically distributed drawn from the common distribution $G(\beta)$, where $G(\underline{\beta})=0$, 
$G(\bar{\beta})=1$, and $G(\beta)$ is strictly increasing and differentiable over the interval $(\underline{\beta}, \bar{\beta})$.

Assumption 2 International shipping requires a contract between a shipper and an importing firm. The contract size for firm $i$ is equal to $\lambda D_{i}$, where $0<\lambda<1$ and $D_{i}$ is $i$ 's annual demand for shipping. Each contract is subject to a fixed cost $A$.

Assumption 3 Firms have an outside opportunity of transportation at the freight rate $\gamma$ (e.g., through an indirect route), which is more expensive than the direct route marginal highest possible cost: $\gamma>\bar{\beta}$. Firms choose the direct route if and only if the freight rate they face does not exceed $\gamma$.

Assumption 4 Both the aggregate and firm-level demands for shipping are determined by exogenous factors and are not affected by freight rate on a given route unless freight rate exceeds $\gamma$.

The exogenous factors determining the demand for shipping on a given route may include comparative advantage, distance, market size, demand for variety, scale economies, etc.

The sequence of actions in the market is as follows. When firm $i$ needs to sign a new contract, it sends a quote request to each shipper on a given route. The quote contains information about the contract size $\lambda D_{i}$. Shippers respond with a shipper-firm-time specific quote $q_{c i t}$. A firm then accepts the lowest quote, which we denote as $\min _{c}\left\{q_{c i t}\right\}$.

\subsection{Equilibrium}

We first consider the scenario with more than one shipper, $n_{c}>1$. We start by defining the valuation of a contract by shipper $c$ as the maximum possible profit from a given contract for $c$. Since the freight rate on a given route is bounded from above by the outside rate $\gamma$, the $c^{\prime}$ s valuation of a contract with an importing firm $i$ in time period $t$ can be calculated as:

$$
v_{c i t}=\left(\gamma-\beta_{c t}\right) \lambda D_{i}-A,
$$

where $\beta_{c t}$ and $A$ are the marginal and per-contract costs of $c$; and $D_{i}$ is $i^{\prime}$ s annual demand for shipping. From equation (2), valuation $v_{c i t}$ is a linear function of the shipper's marginal cost $\beta_{c t}$. 
Thus, for a given importing firm $i$, the cumulative distribution function (cdf) of $v_{c i t}$, $G$, can be expressed in terms of $F$ :

$$
F(v)=G\left(\gamma-\frac{v+A}{\lambda D_{i}}\right)
$$

where $F(\underline{v})=0, F(\bar{v})=1$, with $\underline{v}=(\gamma-\bar{\beta}) \lambda D_{i}-A$ and $\bar{v}=(\gamma-\underline{\beta}) \lambda D_{i}-A$, and the properties of $G(v)$ are defined by Assumption 1. This transformation allows us to frame the profit-maximizing problem of shipper $c$ through the prism of the First-Price Sealed-Bid (FPSB) auction. The standard

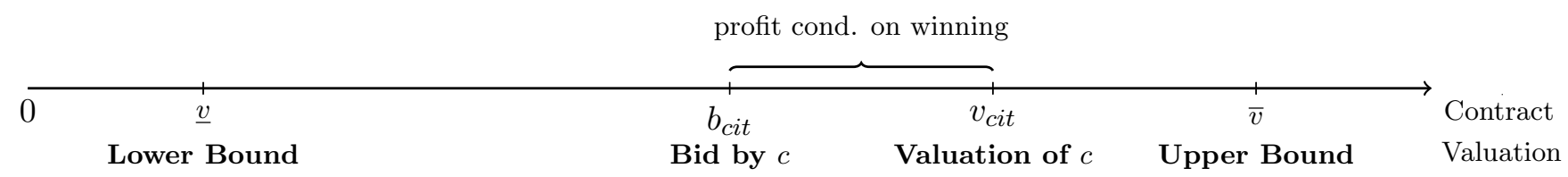

Figure 3: Contract Valuation and Bid

solution of this problem are provided in multiple textbooks (e.g., Milgrom, 2004); we illustrate it by Figure 3. The profit-maximizing bid by shipper $c$ is equal to its valuation, $v_{c i t}$, minus the interval, separating $v_{c i t}$ from the expected next highest valuation: $b_{c i t}=v_{c i t}-\frac{\int_{v}^{v_{c i t}} F^{n_{c}-1}(\tilde{v}) d \tilde{v}}{F^{n_{c}-1}\left(v_{c i t}\right)} \quad \forall n_{c}>1$, where $F^{n_{c}-1}\left(v_{c i t}\right)$ is the probability that if one takes $n_{c}-1$ draws from $F(\cdot)$, all of them will be below $v_{c i t}$. The length of this interval is the profit of $c$ conditional on winning the contract, and, as illustrated by Figure 4 , it is also equal to the the contract quote submitted by the bidder $c$ minus the contract's cost for $c$ :

$$
q_{c i t}-\left(\beta_{c i t} \lambda D_{i}+A\right)=v_{c i t}-b_{c i t}
$$

That is, a higher bid corresponds to a lower quote.

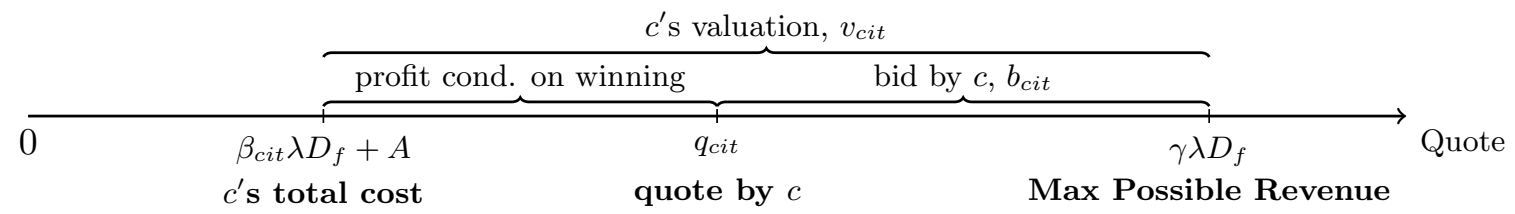

Figure 4: Shipper's quote.

Since quote is a decreasing function of the bid (see eq. (4)), the highest bid corresponds to the lowest quote. From auction theory, the revenue from the FPSB auction is equal to the second 
highest valuation, $\mathrm{E}\left[\left\{b_{\left(n_{c}-1\right) i t}\right]\right.$, (e.g., Milgrom, 2004) ${ }^{26}$ and, from equation (2), the expected second highest valuation is a function of the expected second lowest marginal cost, $\mathrm{E}\left[\beta_{2 t}\right]$ :

$$
\mathrm{E}\left[\max _{c}\left\{b_{c i t}\right\}\right]=\mathrm{E}\left[\left\{b_{\left(n_{c}-1\right) i t}\right]=\left(\gamma-\mathrm{E}\left[\beta_{2 t}\right]\right) \lambda D_{i}-A\right.
$$

By plugging this result in (4) and using equation (2), we can derive the expected minimum quote:

$$
\mathrm{E}\left[\min _{c}\left\{q_{c i t}\right\}\right]=\mathrm{E}\left[\beta_{2 t}\right] \lambda D_{i}+A
$$

from which the expected equilibrium freight faced by firm $i$ under non-monopoly $\left(n_{c}>1\right)$ is:

$$
f_{i t}^{*}\left(n_{c}>1\right)=\frac{\mathrm{E}\left[\min _{c}\left\{q_{c i t}\right\}\right]}{\lambda D_{i}}=\mathrm{E}\left[\beta_{2 t}\right]+\frac{A}{\lambda D_{i}} .
$$

Under a monopoly shipper, however, the only binding freight rate is the outside opportunity rate, $\gamma$, since there is no threat of being undercut by other shippers on the same route. Thus, the profit-maximizing monopolist will charge the binding rate $\gamma: 27$

$$
f_{i t}^{*}\left(n_{c}=1\right)=\gamma
$$

\subsection{Predictions}

Equilibrium results allow us to derive model's predictions.

Proposition 1 Monopoly shipper charges the same freight rate to all firms on a route.

Proof. Follows directly from equation (8).

Proposition 2 With more than one shipper, the freight rate decreases in the:

(i) firm's annual demand for imports demand $\lambda D_{i}$;

(ii) number of shippers $n_{c}$.

\footnotetext{
${ }^{26}$ The bidder with the highest valuation bids at the level of the expected second highest valuation.

${ }^{27}$ An implicit assumption here is that $\gamma$ is greater than the average cost of shipping. Otherwise, the route will not be served at all.
} 
Proof. Part (i) follows directly from the last summand of equation (7). Part (ii) relies on the very general result in statistics that for any well-behaved monotonically increasing on a given interval cdf, the expected $k$ th-smallest of $n$ random variables decreases in $n$ (in our case in $n_{c}$.

Our predictions can be considered as providing micro-foundations for bargaining power in the two-sided markets, in which both sides get a share of the surplus. The per-unit surplus is the difference between the equilibrium freight rate charged by the shipper to the firm and the shipper's average cost of transporting goods. The shipper's share of the surplus increases in shippers concentration with the monopoly shipper getting the entire surplus.

\subsection{Discussion: Alternative Models}

Some of our predictions are consistent with other types of models. For comparison, we briefly describe them below.

Competitive markets with heterogeneous sellers and search frictions. Price dispersion in competitive markets can arise due to cost heterogeneity and informational frictions (e.g., Jensen, 2007; Aker, 2010; Goyal, 2010; Allen, 2014). If shippers are heterogeneous in costs and firms find it suboptimal (due to search cost) to check each available freight rate, even less efficient shippers will be hired, which results in price dispersion. The expected payoff of search is greater for firms with larger shipments. These firms respond by searching more extensively and thus finding a lower freight rate with higher probability. One would need to make additional assumptions in these models for why firms with greater annual demands would face lower freight rates after one controls for the current shipment size. Another important feature of these models which differentiates them from ours is the freight dispersion due to the assortative matching: firms with larger shipments are more likely to face lower freight rates because they are more likely to be serviced by more efficient shippers. In our model, instead, the same shipper chargers lower freight rates to firms with larger contracts.

Two-sided markets have been explored in areas of economics and finance. Since we are particularly interested in the price formation of a homogenous good or service - in our case, maritime

\footnotetext{
${ }^{28}$ The exact formula for the expected $k$ th-smallest of $n$ random variables is given by $\mathrm{E}\left[\beta_{k / n}\right]=$ $\int_{\underline{\beta}}^{\bar{\beta}} \beta \frac{n !}{(k-1) !(n-k) !} g(\beta) G(\beta)^{k-1}(1-G(\beta))^{n-k}$, where $g(\beta)$ and $G(\beta)$ are the pdf and cdf, respectively.
} 
transportation on a given route - the most relevant is the literature on the financial over-the-counter (OTC) markets (e.g., Duffie et al. 2005) with one type of asset ${ }^{29}$ In these markets, the price is determined through the bilateral bargaining process, which depends on each side's alternatives. The model by Duffie et al. (2005) predicts that dealers sell assets to more sophisticated, larger investors at lower prices than to less sophisticated, smaller investors 30 This price dispersion disappears though in the case of a monopoly dealer. These predictions are in line with the predictions of our model. The OTC models, however, are tailored towards the specifics of financial markets and would require significant work to modify them to the context of shipping markets.

\section{Explaining the heterogeneity in freight - Chile}

\subsection{Empirical Methodology}

Our main objective is to estimate the causal effect of the importing firm size on the specific freight rates paid by firms. Estimating equation (9) represents our baseline empirical model of the determinants of freight rate faced by importing firm $f$ for its shipment $s$ on route $r$ for good $g$ from the country of origin $o$ in year $y$-month $m$ :

$$
\begin{aligned}
& \ln F R T_{f s}^{\text {rgym }}=\alpha_{0}+\alpha_{1} \ln \text { Price }_{\text {ofs }}^{\text {rgym }}+\alpha_{2} \ln \text { FirmImports } \\
& f(-s) \\
&+ \alpha_{3} \ln \text { Shipment }_{f s}^{\text {rgym }}+\alpha_{4} \ln (\text { Val } / \text { Wgt })_{f s}^{\text {rgym }}+\alpha^{r g y m}+\alpha^{c}+\nu_{f s}^{\text {rgym }},
\end{aligned}
$$

where

Price $_{\text {ofs }}^{\text {rgym }}$ represents the price of product $g$ imported from the country of origin $o$ in shipment $s$ on route $r$ in year $y$ and month $m$ by firm $f$;

FirmImports $f_{f(-s)}^{y}$ represents the firm's annual f.o.b import value or weight on all sea routes from an exporter-country 31 , excluding the current shipment $s$;

\footnotetext{
${ }^{29}$ Several papers focus on the two-sided markets in international trade (e.g., Benguria, 2015, Eaton et al., 2016, Bernard et al. 2018). These papers, however, focus on other than price aspects of these markets, such as positive and negative assortative matching, adjustment to trade shocks, etc.

${ }^{30}$ In Duffie et al. (2005), the more sophisticated firms (investors) are the ones with more frequent transactions. However, since in their model, the transaction size is limited to one unit, more frequent transactions automatically correspond to larger firm size.

${ }^{31}$ In the robustness check section, we show that the results are robust to other definitions of firm's size
} 
Shipment $V_{f s}^{\text {rgym }}$ represents the f.o.b. value or weight of firm $f$ 's current shipment of product $g$ imported on route $r$ in year $y$ and month $m$;

$(\mathrm{Val} / \mathrm{Wgt})_{f s}^{r g y m}$ represents the value-to-weight ratio of the good shipped;

$\alpha^{r g y m}$ represents route $r$-good $g$-year $y$-month $m$ specific determinants of freight rates, common to all firms and shipments, such as: distance travelled, loading and unloading costs associated with the port infrastructure and efficiency, product type, tariffs, total value of trade on a route, competition and the average size of shippers, product's import demand elasticity, the haul problem, volatility in the bilateral exchange rate, etc. 32

$\alpha^{c}$ represents the shipper $c$-specific determinants of freight rates, common to all routes, goods, and firms, which we include to control for the potential heterogeneity in the efficiency of shippers (Asturias, 2019) such as shipper's efficiency and scale in transport services;

$\nu_{f s}^{r g y m}$ is the idiosyncratic component, assumed to be independent and identically distributed.

Our primary variable of interest is FirmImports, which we predicted to have a negative effect on the freight rate. In line with the existing literature, the freight rate is expected to increase in Price and $\mathrm{Val} / \mathrm{Wgt}$ and to decrease in ShipmentV. Omitting these variables is likely to cause the omitted variables bias because previous literature has documented that larger importers import more expensive higher-quality goods, which tend to be heavier goods, and that larger firms import heavier shipments (Holmes and Singer, 2018). By including route-product-year-month and shipper fixed effects, we identify the coefficients using variation across firms that import the same product on a given route, year and month, and the same shipper. The fixed effects also wash out any routeproduct-year-month characteristics that can affect specific freight rates. Thus, we can eliminate any omitted-variable bias concerns by controlling for all route-product-year-month-specific and shipperspecific variables that can affect the freight rate and be correlated with our regressors.

Hummels and Skiba $(2004)$ have shown that product price increases in the specific freight rate, which is known as the Alchian-Allen effect. To control for the potential reverse causality between price and specific freight within a route, we estimate equation (9) using two-stage least squares

\footnotetext{
${ }^{32}$ These determinants of freight rate were identified by Hummels and Skiba (2004); Blonigen and Wilson (2008);
} Hummels et al. (2009); Wong (2018); Asturias (2019); Lashkaripour (2019), among others. Furthermore, the fixed effects can also at least partially control for the geography and networks effects highlighted by Brancaccio et al. (2017). 
(2SLS) in which we instrument the log of product's price with the log of the real GDP per capita of the product's country of origin. As described in Table 1, there is sufficient variation in the product's country of origin on a given route so that our instrument is not collinear with route-product-yearmonth fixed effects. Our choice was guided by previous theoretical and empirical studies that found a positive correlation between product prices and exporter's per capita real GDP (e.g., Schott, 2004 . Hummels and Klenow, 2005, Lugovskyy and Skiba, 2015). We also expect that the real GDP per capita of the country of origin is not correlated with the error term, $\nu_{f s}^{\text {rgym }}$, once we control for route-product-year-month fixed effects.

Since the value of the current shipment and the specific freight rate can be jointly determined, we instrument the log of current shipment with the log of the average of the firm's value of other shipments on the same route. Once we control for route-product-year-month fixed effects and the price of the product shipped, we expect that the log of the firm's average value of other shipments on the same route is not correlated with the error term, $\nu_{f s}^{r g y m}$. Next, we augment estimating equation (9) by introducing an interaction term between the importing firm annual imports on sea routes from a country-exporter and a MonopolyDummy that takes values equal to 1 if the route-specific Herfindahl index (constructed using the shipper shares) is greater or equal to 0.8 and 0 otherwise:

$$
\begin{aligned}
\ln F R T_{f s}^{r g y m} & =\alpha+\alpha_{1} \ln \text { Price }_{\text {ofs }}^{\text {rgym }}+\alpha_{2} \ln \text { FirmImports }_{f(-s)}^{y}+\alpha_{3} \ln \text { Shipment }_{f s}^{\text {rgym }} \\
& +\alpha_{4} \ln (\text { Val } / \text { Wgt })_{f s}^{r g y m}+\alpha_{5} \ln \text { FirmImports }_{f(-s)}^{y} * \text { MonopolyShipper }^{r y} \\
& +\alpha^{r g y m}+\alpha^{c}+\nu_{f s}^{r g y m}
\end{aligned}
$$

Our model predicts for the interaction term to have a positive effect on the freight rate and to offset the negative effect of FirmImports. We estimate both equations (9) and (10) using 2SLS as described above. Our results show that the instruments are statistically valid based on first-stage F-stats, under-identification, and weak identification tests.

\subsection{Results}

Table 4 reports IV estimates of equations (9) for 2007-2009 using non-bulk commodities on routes with ten importing firms or more. The first four columns show the estimates for all available sea 
routes, even if some ports of departure were not precisely identified (e.g., "Other ports of China" or "Other ports of Asia"), while the last four columns show the estimates for when both the port of departure (e.g., "Miami") and the port of landing (e.g., "San Antonio") were identified. Columns (1)-(3) and (5)-(7) of Table 4 report the results based on the Restricted sample of the single-product shipments, while Columns (4) and (8) are based on the Full sample which also includes multiproduct shipments. As discussed above, the freight rate for each product is mismeasured in the multi-product shipments. Thus, the full-sample results are included in Table 4 for comparison only. When we include multi-product shipments, we cannot identify the weight per unit of each product in the shipment because the weight is reported for the entire shipment. Thus, the price coefficient in column (4) and column (8) suffers from upward omitted variable bias since pricier products tend to weigh more. To compare the results using the multi-product shipments with the ones using only single-shipments, in column (3) and (7), we also omit weight per unit. As expected, we find a strong pro-iceberg bias in multi-product shipments.

Table 4: The effect of firm's annual imports on the specific freight rate, 2007-2009.

\begin{tabular}{|c|c|c|c|c|c|c|c|c|}
\hline & \multicolumn{4}{|c|}{ All Ports } & \multicolumn{4}{|c|}{ Only Identified Ports } \\
\hline & \multicolumn{3}{|c|}{$\begin{array}{l}\text { Restricted } \\
\text { Sample }\end{array}$} & \multirow{2}{*}{$\begin{array}{c}\begin{array}{c}\text { Full } \\
\text { Sample }\end{array} \\
\text { Value } \\
\end{array}$} & \multicolumn{3}{|c|}{$\begin{array}{l}\text { Restricted } \\
\text { Sample }\end{array}$} & \multirow{2}{*}{$\begin{array}{c}\text { Full } \\
\text { Sample } \\
\text { Value }\end{array}$} \\
\hline & Weight & & & & Weight & & & \\
\hline Log(Price) & $\begin{array}{c}0.42 \\
(0.27)\end{array}$ & $\begin{array}{c}0.52^{* *} \\
(0.25)\end{array}$ & $\begin{array}{c}0.62^{* * *} \\
(0.21)\end{array}$ & $\begin{array}{c}0.90^{* * *} \\
(0.18)\end{array}$ & $\begin{array}{c}0.24 \\
(0.24)\end{array}$ & $\begin{array}{c}0.40^{* *} \\
(0.20)\end{array}$ & $\begin{array}{c}0.53^{* * *} \\
(0.17)\end{array}$ & $\begin{array}{c}0.82^{* * *} \\
(0.19)\end{array}$ \\
\hline Log(Shipment) & $\begin{array}{l}-0.06 \\
(0.09)\end{array}$ & $\begin{array}{c}-0.14^{* * *} \\
(0.05)\end{array}$ & $\begin{array}{c}-0.12^{* *} \\
(0.05)\end{array}$ & $\begin{array}{c}-0.21^{* * *} \\
(0.05)\end{array}$ & $\begin{array}{c}-0.14^{*} \\
(0.08)\end{array}$ & $\begin{array}{c}-0.16^{* * *} \\
(0.05)\end{array}$ & $\begin{array}{c}-0.13^{* *} \\
(0.05)\end{array}$ & $\begin{array}{c}-0.20^{* * *} \\
(0.06)\end{array}$ \\
\hline $\begin{array}{l}\text { Log(Firm's imports) } \\
\text { (excludes current shipment) } \\
\text { Log(Weight/unit) }\end{array}$ & $\begin{array}{c}-0.04^{* * *} \\
(0.01) \\
0.59^{* *} \\
(0.27)\end{array}$ & $\begin{array}{c}-0.03^{* * *} \\
(0.01) \\
0.50 * * \\
(0.23)\end{array}$ & $\begin{array}{c}-0.04^{* * * *} \\
(0.01)\end{array}$ & $\begin{array}{c}-0.03^{* * *} \\
(0.01)\end{array}$ & $\begin{array}{c}-0.04^{* * *} \\
(0.01) \\
0.77^{* * *} \\
(0.24)\end{array}$ & $\begin{array}{c}-0.03^{* * *} \\
(0.01) \\
0.62 * * * \\
(0.18)\end{array}$ & $\begin{array}{c}-0.03^{* * *} \\
(0.01)\end{array}$ & $\begin{array}{c}-0.03^{* * *} \\
(0.01)\end{array}$ \\
\hline Under-identification te & 5.04 & 4.9 & 4.8 & 3.38 & 4.28 & 4.24 & 4.22 & 3.09 \\
\hline Under-identification p-value & 0.02 & 0.03 & 0.03 & 0.07 & 0.04 & 0.04 & 0.04 & 0.08 \\
\hline Weak identification test & 19.10 & 41.12 & 41.9 & 14.11 & 16.49 & 43.47 & 49.87 & 14.73 \\
\hline No. Routes & 260 & 260 & 260 & 282 & 177 & 177 & 177 & 190 \\
\hline No. Obs & 482,873 & 482,873 & 482,873 & $1,561,375$ & 350,435 & 350,435 & 350,435 & $1,118,560$ \\
\hline
\end{tabular}

Notes: IV regressions. Standard errors are clustered by route and country of origin. All variables are mean-differenced by HS8-route-year-month and shipper. *, **,*** significant at 10, 5, and 1 percent, respectively.

Our results are in line with our predictions. In all specifications and across all samples, specific freight rate decreases in the firm's annual import, measured by either value or weight, from an exporting country. Based on the value of the estimated elasticities, increasing the value (weight) 
of imports by a firm from an exporting country by $10 \%$ decreases the specific freight rates by $0.3 \%$ $(0.4 \%)$, holding other factors constant. The estimates are statistically significant at $1 \%$ or less. These magnitudes are quite notable: for a given port-to-port route and product, the 90th percentile firm in terms of value imports at about $13 \%$ lower specific freight rate than the 10 th percentile firm. If instead, firms are ranked by weight, the corresponding freight rate dispersion increases to 20\%. Table 5 also reports the negative gap in specific freight rates paid by 95 th $/ 5$ th 80 th $/ 20$ th, 75 th $/ 25$ th, 95 th $/ 50$ th, and 50th/20th percentile firms in terms of value and weight.

Table 5: The gap in specific freight rate paid by a large and a small firm

\begin{tabular}{l|c|c|c|c}
\hline \hline Annual Firm's Imports & \multicolumn{3}{|c}{ Value } & \multicolumn{2}{c}{ Weight } \\
\hline & $\hat{\alpha_{2}}=-0.03$ & $\begin{array}{c}\hat{\alpha_{2}}=-0.03, \\
\hat{\alpha_{3}}=-0.16\end{array}$ & $\hat{\alpha_{2}}=-0.04$ & $\begin{array}{c}\hat{\alpha_{2}}=-0.04 \\
\hat{\alpha_{3}}=-0.14\end{array}$ \\
\hline 95th/5th & $-16 \%$ & $-48 \%$ & $-25 \%$ & $-61 \%$ \\
$90 \mathrm{th} / 10 \mathrm{th}$ & $-13 \%$ & $-40 \%$ & $-20 \%$ & $-50 \%$ \\
$80 \mathrm{th} / 20 \mathrm{th}$ & $-9 \%$ & $-30 \%$ & $-13 \%$ & $-37 \%$ \\
$75 \mathrm{th} / 25 \mathrm{th}$ & $-7 \%$ & $-24 \%$ & $-11 \%$ & $-32 \%$ \\
$95 \mathrm{th} / 50 \mathrm{th}$ & $-10 \%$ & $-29 \%$ & $-15 \%$ & $-35 \%$ \\
$50 \mathrm{th} / 5 \mathrm{th}$ & $-6 \%$ & $-27 \%$ & $-12 \%$ & $-40 \%$ \\
\hline \hline
\end{tabular}

Notes: 1. Columns (1) and (3) present the specific freight rate paid by the firm with $x$ annual imports compared to the firm with $y$ annual imports is lower by $\left(1-\left(\frac{x}{y}\right)^{\hat{\alpha_{2}}}\right) * 100 \%$, where $x>y$ and $\hat{\alpha_{2}}=-0.03$ when imports are measured in US dollars and $\hat{\alpha_{2}}=-0.04$ when measured in kilograms from Table 4 .

2.Columns (2) and (4) take into account the average shipment value and then weight of the firm with $x$ or $y$ annual imports $-s_{x}$ and $s_{y}$, respectively. In this case, the specific freight rate paid by the firm with $x$ annual imports to the firm with $y$ annual imports is lower by $\left(1-\left(\frac{x}{y}\right)^{\hat{\alpha_{2}}} *\left(\frac{s_{x}}{s_{y}}\right)^{\hat{\alpha_{3}}}\right) * 100 \%$, where $x>y$ and $\hat{\alpha_{2}}=-0.03$ and $\hat{\alpha_{3}}=-0.16$ when measured in US dollars and $\hat{\alpha_{2}}=-0.04$ and $\hat{\alpha_{3}}=-0.14$ when measured in kilograms from Table 4 .

In line with the existing literature, freight rate decreases in the shipment size, with the elasticities of (-0.16) for shipment size measured by value and (-0.14) for the shipment size measured by weight (see Table 4). We also find that firm size and shipment size are positively correlated, meaning that larger firms tend to import in larger shipments. If we take this factor into account, the predicted negative gap in specific freight rates paid by $90 \mathrm{th} / 10$ th percentile firms in terms of value reaches a stunning $40 \%$ and 50\% in terms of weight in 2007 (Columns (2) and (4) of Table 5).

Previous literature has identified a strong effect of price on the freight rate. Our results are mixed. When firm and shipment sizes are defined by value, the estimate is statistically significant, with the magnitude of elasticity, 0.40 (in the restricted sample), being somewhat lower than those in Hummels and Skiba (2004) — 0.61 for Latin American importers — and Hummels et al. (2009) — 
0.55. When firm and shipment sizes are defined by weight, however, the estimate is not statistically significant at $10 \%$, while the corresponding magnitude of 0.24 being even smaller. Thus, we claim a much lower extent of ad-valorem nature of freight rate than the previous literature, which did not control for shipment composition and firm and shipment size effects.

In line with Lashkaripour (2019), we find that freight rate increases in the weight per unitthe corresponding elasticity varies between 0.5 and 0.77. As documented by Holmes and Singer (2018), the relevant capacity limitation in a container is "virtually always volume, not weight." We conjecture that the estimated magnitudes are so high because the weight per unit may serve as a proxy of volume per unit, especially after controlling for product type using fixed effects.

Table 6: The effect of the monopoly power on a given route on the specific freight rate.

\begin{tabular}{l|cc|cc}
\hline \hline & \multicolumn{2}{|c}{ All Ports } & \multicolumn{2}{c}{ Only Identified Ports } \\
\hline & Value & Weight & Value & Weight \\
\hline $\log ($ Price$), \alpha_{1}$ & $0.52^{* *}$ & 0.42 & $0.40^{* *}$ & 0.24 \\
& $(0.24)$ & $(0.27)$ & $(0.20)$ & $(0.24)$ \\
$\log \left(\right.$ Shipment value), $\alpha_{3}$ & $-0.14^{* * *}$ & -0.06 & $-0.16^{* * *}$ & $-0.14^{*}$ \\
& $(0.05)$ & $(0.09)$ & $(0.05)$ & $(0.08)$ \\
$\log \left(\right.$ Firm's imports), $\alpha_{2}$ & $-0.04^{* * *}$ & $-0.04^{* * *}$ & $-0.03^{* * *}$ & $-0.04^{* * *}$ \\
(excludes current shipment) & $(0.01)$ & $(0.01)$ & $(0.01)$ & $(0.01)$ \\
Log(Firm's imports)*MonopolyShipper, $\left.\alpha_{5}\right)$ & $0.03^{* *}$ & $0.03^{* * *}$ & $0.03^{*}$ & 0.03 \\
(excludes current shipment) & $(0.02)$ & $(0.02)$ & $(0.02)$ & $(0.02)$ \\
Log(Weight/unit), $\alpha_{4}$ & $0.50^{* *}$ & $0.59^{* *}$ & $0.62^{* * *}$ & $0.77^{* * *}$ \\
& $(0.22)$ & $(0.27)$ & $(0.18)$ & $(0.24)$ \\
\hline Under-identification test & 4.90 & 5.05 & 4.17 & 4.29 \\
Under-identification p-value & 0.03 & 0.02 & 0.04 & 0.04 \\
Weak identification test & 41.43 & 19.20 & 47.48 & 16.50 \\
No. Routes & 260 & 260 & 177 & 177 \\
No. Obs & 482,873 & 482,873 & 350,435 & 350,435 \\
\hline F-stat: $\alpha_{2}+\alpha_{5}=0$ & 0.76 & 0.85 & 0.16 & 0.20 \\
p-value & $(0.38)$ & $(0.35)$ & $(0.69)$ & $(0.65)$ \\
\hline \hline
\end{tabular}

Notes: IV regressions. Standard errors are clustered by route and country of origin. All variables are mean-differenced by HS8-route-year-month and shipper. *, **, *** significant at 10, 5, and 1 percent, respectively.

As predicted by our model, the price dispersion disappears in routes served by a monopoly shipper. This result can be seen from an F-test reported in Table 6, which shows that the firm's size effect is offset by its interaction with a monopoly indicator 33 We document that, in our sample, the number of routes with a monopoly shipper decreases over time: for the routes that firms use

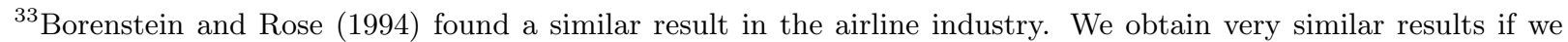
interact firm size with the shipper HHI rather than with the shipper monopoly dummy. The results are available upon request.
} 
in all years of our data, the share of routes with a monopoly shipper has monotonically declined from $21 \%$ in 2007 to $5 \%$ in 2015 (Figure 5 shows the shift in the distribution over time). Thus, the freight rate dispersion between large and small importers is likely to be present on more and more routes over time.

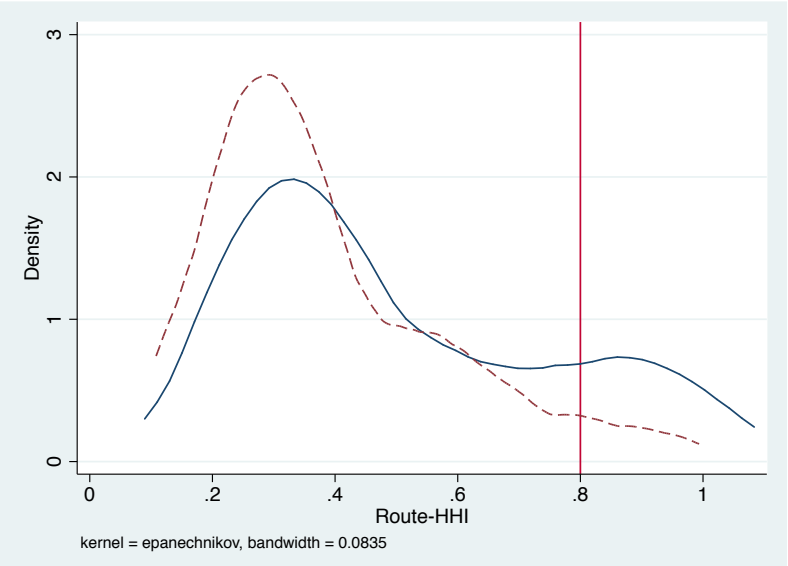

Figure 5: The distribution of the route-shipper HHI in 2007 (solid line) and 2015 (dashed line).

\subsection{Robustness Checks}

\subsubsection{Robustness Checks using Chilean data}

To check the sensitivity of our results, we perform several robustness exercises. We start by reestimating eq. (9) with alternative definitions of the firm size, measured as either its annual import value on a given port-to-port route or as its annual import value on all routes. We also account for the possibility that shippers take into account the firm's previous year's import value, so the firm size is defined based on its lagged annual import value. The estimates are reported in Table 8, All the results are consistent with our main estimates.

The second set of exercises estimates our baseline regression using the 2014-2015 data. The estimates using only routes with identified ports are shown in Column (1) of Table10. The results are qualitatively similar to the ones obtained on the 2007-2009 data even though the magnitudes are slightly changed. Column (2) of the same table augments the specification by including an additional dummy variable ImpDummy that takes values equal to 1 if the importing firm was 
responsible for the delivery process (constructed using the Incoterms information in the data) and 0 if the exporting firm was the one responsible. The estimated coefficient on the ImpDummy is positive and statistically significant at $1 \%$ or less, suggesting that, ceteris paribus, freight rates tend to be higher if the importing firm is responsible for arranging transportation. When we interact the ImpDummy with the firm's size in Column (3), the estimated coefficient on the interaction term is negative and statistically significant at $1 \%$ or less. That is, if the importing firm is responsible for delivery, the firm size elasticity of specific freight rate doubles in magnitude. Our results are also robust to estimating the main specification (9) on both bulk and non-bulk commodities (see Table 9 and to estimating it on a sample that includes smaller routes - with more than five firms per route (see Table 11).

\subsubsection{Including Exporting Firm Size, Colombian Imports}

Existing research suggests the possibility of either positive or negative assortative matching between exporting and importing firms 34 Thus, importing firm size may be correlated with the size of the matching exporting firm. If larger exporting firms are more likely to negotiate freight rates, this potential correlation might have biased our estimates of the firm size elasticity of freight. Specifically, our estimates may be biased downward (more negative) under a positive assortative matching and toward zero under a negative assortative matching ${ }^{35}$ Motivated by these considerations, we use the Colombian Imports dataset, which includes the identities of both importing and exporting firms, to check the sensitivity of our results to including the exporting firm size.

These data, obtained from the Colombian Customs Office ${ }^{36}$ contain all the variables we use in the Chilean dataset for the same period of 2007-2009, except for the port of loading and port of unloading. Consequently, we define a route as the (country of departure)-to-Colombia. Observing the identity of the exporting firm allows us to control for the exporting firm trade value on a

\footnotetext{
${ }^{34}$ For example, assortative matching was found by Blum et al. (2010) for Chile and Colombia as well as Argentina and Chile firm-to-firm matches; by Benguria (2015) for Chile and France firm-to-firm matches. Bernard et al. (2018), on the other hand, document the negative degree assortativity for the Norwegian exporting firms and their importing counterparts.

${ }^{35}$ Recall that, in the Chilean Imports data, we do not observe the identities of exporting firms and thus are not able to account for their sizes.

${ }^{36}$ The dataset is obtained from Datamyne, a company that specializes in documenting import and export transactions worldwide. For more detail, please see www.datamyne.com.
} 
Table 7: The effect of firm's annual imports on the freight rate, Colombia, 2007-2009.

\begin{tabular}{lccc}
\hline \hline Dependent variable: & \multicolumn{3}{c}{ Specific Freight } \\
\hline Log(Price) & $0.22^{* *}$ & $0.22^{* *}$ & 0.12 \\
& $(0.09)$ & $(0.09)$ & $(0.11)$ \\
Log(Shipment value) & 0.02 & 0.02 & -0.02 \\
& $(0.05)$ & $(0.05)$ & $(0.05)$ \\
Log(Firm's imports) & $-0.04^{* * *}$ & $-0.04^{* * *}$ & \\
& $(0.01)$ & $(0.01)$ & \\
Log(Partner's exports) & $-0.01^{* * *}$ & & $-0.02^{* * *}$ \\
& $(0.00)$ & & $(0.00)$ \\
Log(Weight/unit) & $0.74^{* * *}$ & $0.74^{* * *}$ & $0.84^{* * *}$ \\
& $(0.07)$ & $(0.07)$ & $(0.09)$ \\
\hline Underidentification test & 2.53 & 2.53 & 1.92 \\
Underidentification p-value & 0.11 & 0.11 & 0.17 \\
Weak identification test & 92.42 & 92.42 & 90.91 \\
No. Routes & 78 & 78 & 78 \\
No. Obs & 549,376 & 549,376 & 549,379 \\
\hline
\end{tabular}

Notes: IV regressions. Standard errors are clustered by route. All variables are mean-differenced by product, route, year; shipper fixed effects are included. Standard errors are clustered by route. All variables are mean-differenced by product, route, year, and month. ${ }^{*}, * *, * * *$ significant at 10,5 , and 1 percent, respectively.

given route. The median exporting firm on a given route is roughly of the same size as a median Colombian firm, and the overall distributions of exporting and importing firms are very similar.

Other than using the country-to-country rather than a port-to-port definition of a route, our empirical specification for the Colombian dataset is the same as the one used for the Chilean data (eq. 9p. Table 7 presents the results. The freight rate decreases in the importer's trade size even when we control for the exporter's trade size on a route. Importantly, the importing firm size elasticity of freight rate is the same as the one we estimated on the Chilean dataset, and it is four times higher than the exporting firm size elasticity of freight rate (Column 1 of Table 7). This difference in the magnitudes is in line with ours and Teshome (2018)'s findings of the leading role of importing firms in negotiating freight rates.

\section{Implications for Input Prices, TFP, and Firm Size Dispersion}

While input prices are known to vary across firms, the precise, apple-to-apple comparison of these prices is nontrivial due to the variation in input quality and is typically conducted for industries with homogenous inputs and outputs. The identified sources of variation in input prices include geography, suppliers' marginal cost, and within-supplier price differences due to heterogenous bar- 
gaining powers of buyers (e.g., Atalay, 2014). Our results expand the scope of this literature in two ways. On the one hand, the maritime port-to-port shipping for a given product is a reasonably homogeneous service with no apparent variation in quality, which enables the apple-to-apple comparison of freight rates across importing firms. On the other hand, freight rate is a cost shifter for the whole range of imported products, which allows examining the effect of the firm size on input prices for various types of inputs, including the vertically-differentiated ones.

To quantify the effect of firm size $D$ on imported input price $P_{I}$, we start by deriving the firm size elasticity of the price $\delta \equiv \frac{\partial P_{I}}{\partial D} \frac{D}{P_{I}}$, as a function of the firm size elasticity of freight rate $\varepsilon \equiv \frac{\partial f}{\partial D} \frac{D}{f}$. The delivered price of an imported input, $P_{I}$, is a function of the factory price $p$ and trade costs:

$$
P_{I}(D)=(p(1+i)+f(D))(1+t),
$$

where $f(D)$ is the freight rate, $i$ is the insurance rate and $t$ is the tariff rate ${ }^{37}$ From this equation, the firms size elasticity of the delivered price $\delta$ can be derived as:

$$
\delta=\frac{\partial f(D)}{\partial D}(1+t) \frac{D}{P_{I}(D)}=\frac{f(D)}{p(1+i)+f(D)} \varepsilon
$$

Our estimate of $\varepsilon=-.04$ (Table 4) and the calculated average ad-valorem equivalent of the freight rate $\frac{f}{p(1+i)+f}=0.08$ suggest the value of $\delta=-0.0032 .38$ Given that the annual imports of the 90th percentile firm (by weight) are 257 heavier than that of the 10 th percentile firm, their delivered prices will differ by $\left(1-257^{-0.0032}\right) * 100 \%=1.8 \%$. This price difference further increases to $5.5 \%$ if we take into account that larger firms tend to import in larger shipments ${ }^{39}$ Thus, there will be a pronounced asymmetry in accessing foreign markets by firms of different sizes. Its effect on the firm's input price index depends on the parameters of the production function.

\footnotetext{
${ }^{37}$ Recall that in Chile, the freight rate is imposed on the top of transportation and insurance charges. For brevity, we drop the product, country of loading, and country of origin subscripts.

${ }^{38}$ All calculations are for 2007, but the magnitudes are fairly consistent across years 2007, 2008, and 2009.

${ }^{39}$ Similarly to equation [11, the shipment size elasticity of the delivered price is given by $\delta_{S}=\frac{f(D)}{p(1+i)+f(D)} \varepsilon_{S}$, where $\varepsilon_{S}=-0.14$ is the estimated shipment size elasticity of the freight rate (see Column 5 of Table 4 ). With the average share $\frac{f(D)}{p(1+i)+f(D)}=0.08, \delta_{S}=0.08 *(-0.14)=-0.0112$. Furthermore, the shipment size (by weight) ratio for the 90th-to-10th firm size percentiles is 28 , from which the delivered price paid by the 90th percentile importing firm is $\left(1-28^{-0.0112}\right) * 100 \%=3.7 \%$ lower than that paid by the $10 t h$ percentile firm.
} 
For a Cobb-Douglas production function, the price index of firm $j$ is given by: $\mathbb{P}_{j}=\left(\frac{P_{D j}}{1-\alpha}\right)^{1-\alpha}\left(\frac{P_{I j}}{\alpha}\right)^{\alpha}$, where $P_{D j}$ and $P_{I j}$ are the prices of domestic and imported inputs 40 and $\alpha$ is the share of imports in total expenditure. With the share of imports in Chilean GDP in 2007 being $31.3 \%$ the firm size elasticity of the total price index is $\alpha \delta=-0.001$. Thus, in 2007, the 90th percentile Chilean importing firm faced a $\left(1-257^{-.001}\right) * 100 \%=0.55 \%$ lower price index than a 10th percentile firm. If we also take into account differences in the shipment sizes, this difference increases to $1.7 \%$. These magnitudes also represent the biases in the estimated TFPs between large and small firms when TFP is estimated using the expenditures on inputs rather than inputs' quantities 42

Finally, asymmetric access to imports contributes to a more dispersed distribution of firms. In Melitz (2003) framework, the large-small firm ratio of total revenues is given by:

$$
\frac{r(\underline{c})}{r(\bar{c})}=\left(\frac{\bar{c}}{\underline{c}}\right)^{\sigma-1} \quad \underline{c}<\bar{c},
$$

where $\underline{c}$ is the marginal cost of the large firm, and $\underline{c}$ is the marginal cost of the small firm. If the asymmetry in freight rates reduces the input price for the large firm by $1.7 \%$, it increases the large-to-small firm revenue ratio $(1 / 0.983)^{\sigma-1}$ times. For a $\sigma=5$, it will amount to 1.07 times, or $7 \%$ increase in the revenue ratio due to asymmetric freight rates.

\section{Conclusion}

Consistent with our theoretical predictions, we find that larger firms face lower maritime freight rates even within a narrowly defined product and port-to-port route unless this route is served by a monopoly shipper. Our findings are in sharp contrast with symmetric, either ad-valorem or specific trade costs on a given route - a prevailing assumption in the literature, which is critical for deriving equilibrium conditions and evaluating welfare gains from trade. This asymmetry in access to imports across firms affects input prices, TFP estimation, and magnifies the extent of firm size

\footnotetext{
${ }^{40}$ The price of domestic input may also be firm-specific since it may vary across firms due to geography, idiosyncratic managerial quality, or firm's bargaining power (Atalay, 2014).

${ }^{41}$ The share of imports varies across industries. We report the average for the entire economy based on the World Bank Data.

${ }^{42}$ With a lower price index, larger firms can buy more units of inputs per dollar spent than smaller firms. When this factor is not accounted for, the higher output is assigned to the TFP which is estimated as a residual.
} 
heterogeneity.

\section{References}

Jenny C. Aker. Information from Markets Near and Far: Mobile Phones and Agricultural Markets in Niger. American Economic Journal: Applied Economics, 2(3):46-59, July 2010.

Treb Allen. Information Frictions in Trade. Econometrica, 82:2041-2083, November 2014.

Mary Amiti and Jozef Konings. Trade liberalization, intermediate inputs, and productivity: Evidence from indonesia. American Economic Review, 97(5):1611-1638, December 2007. doi: 10.1257/aer.97.5.1611. URL http://www . aeaweb.org/articles?id=10.1257/aer.97.5.1611.

James E. Anderson and Eric van Wincoop. Trade Costs. Journal of Economic Literature, 42(3): 691-751, September 2004.

Pol Antra s, Teresa C. Fort, and Felix Tintelnot. The Margins of Global Sourcing: Theory and Evidence from US Firms. American Economic Review, 107(9):2514-2564, 2017.

Costas Arkolakis, Arnaud Costinot, and Andres Rodriguez-Clare. New Trade Models, Same Old Gains? American Economic Review, 102(1):94-130, February 2012.

Jose Asturias. Endogenous Transportation Costs. Mimeo, Georgetown University Qatar, 2019.

Enghin Atalay. Materials Prices And Productivity. Journal of the European Economic Association, 12(3):575-611, June 2014. URL https://ideas.repec.org/a/bla/jeurec/ v12y2014i3p575-611.html.

David Atkin and Dave Donaldson. Who's Getting Globalized? The Size and Implications of Intranational Trade Costs. Manuscript, 2015.

Felipe Benguria. The Matching and Sorting of Exporting and Importing Firms: Theory and Evidence. University of Kentucky Mimeo, 2015.

Nicolas Berman, Philippe Martin, and Thierry Mayer. How do Different Exporters React to Exchange Rate Changes? The Quarterly Journal of Economics, 127(1):437-492, 2012. URL https://ideas.repec.org/a/oup/qjecon/v127y2012i1p437-492.html.

Andrew B. Bernard and Swati Dhingra. Importers, Exporters and the Division of the Gains from Trade. Mimeo, London School of Economics, 2019.

Andrew B. Bernard, Andreas Moxnes, and Karen Helene Ulltveit-Moe. Two-Sided Heterogeneity and Trade. The Review of Economics and Statistics, 100(3):424-439, July 2018.

Bruce Blonigen and Wesley Wilson, editors. Handbook of International Trade and Transportation. Edward Elgar Publishing, 2018.

Bruce A. Blonigen and Wesley W. Wilson. Port Efficiency and Trade Flows. Review of International Economics, 16(1):21-36, February 2008. 
Nicholas Bloom, Christos Genakos, Ralf Martin, and Raffaella Sadun. Modern Management: Good for the Environment or Just Hot Air? Economic Journal, 120(544):551-572, May 2010. URL https://ideas.repec.org/a/ecj/econjl/v120y2010i544p551-572.html.

Bernardo S. Blum, Sebastian Claro, and Ignatius Horstmann. Facts and Figures on Intermediated Trade. American Economic Review, 100(2):419-423, May 2010.

Severin Borenstein. Price Discrimination in Free-Entry Markets. The RAND Journal of Economics, 16(3):380-397, Autumn 1985.

Severin Borenstein and Nancy L. Rose. Competition and Price Dispersion in the U.S. Airline Industry. Journal of Political Economy, 102(4):653-683, August 1994.

Giulia Brancaccio, Myrto Kalouptsidi, and Theodore Papageorgiou. Geography, Search Frictions and Endogenous Trade Costs. Technical Report WP 23581, July 2017.

Meghan Busse and Marc Rysman. Competition and Price Discrimination in Yellow Pages Advertising. RAND Journal of Economics, 36(2):378-390, Summer 2005. URL https://ideas.repec. org/a/rje/randje/v36y20052p378-390.html.

Ximena Clark, David Dollar, and Alejandro Micco. Ports efficiency, maritime transport costs, and bilateral trade. Journal of Development Economics, 75:417-450, 2004.

A. Kerem Coşar and Banu Demir. Shipping inside the box: Containerization and trade. Journal of International Economics, 114(C):331-345, 2018. doi: 10.1016/j.jinteco.2018.07. URL https : //ideas.repec.org/a/eee/inecon/v114y2018icp331-345.html.

Darrell Duffie, Nicolae Gârleanu, and Lasse Heje Pedersen. Over-the-counter markets. Econometrica, 73(6):1815-1847, 2005.

Jonathan Eaton and Samuel Kortum. Technology, Geography, and Trade. Econometrica, 70(5): 1741-1779, September 2002.

Jonathan Eaton, David Jinkins, Daniel Yi Xu, and James Tybout. Two-sided Search in International Markets. 2016 Meeting Papers 973, Society for Economic Dynamics, 2016. URL https://ideas . repec.org/p/red/sed016/973.html.

Robert C. Feensta, Robert Inklaar, and Marcel P. Timmer. The Next Generation of the Penn World Table. American Economic Review, 105(10):3150-3182, 2015.

Robert C. Feenstra and John Romalis. International Prices and Endogenous Quality. The Quarterly Journal of Economics, 129(4):477-527, 2014.

Lionel Fontagne, Gianluca Orefice, Roberta Piermartini, and Nadia Rocha. Product standards and margins of trade: Firm-level evidence. Journal of International Economics, 97(1):29-44, 2015.

Kristopher S. Gerardi and Adam Hale Shapiro. Does Competition Reduce Price Dispersion? New Evidence from the Airline Industry. Journal of Political Economy, 117(1):1-37, February 2009. URL https://ideas.repec.org/a/ucp/jpolec/v117y2009i1p1-37.html. 
Aparajita Goyal. Information, Direct Access to Farmers, and Rural Market Performance in Central India. American Economic Journal: Applied Economics, 2(3):22-45, July 2010.

Julia Cajal Grossi, Rocco Macchiavello, and Guillermo Noguera. International Buyers? Sourcing and Suppliers? Markups in Bangladeshi Garments. Mimeo, London School of Economics, 2019.

Juan Carlos Hallak and James Levinsohn. Fooling ourselves: Evaluating the globalization and growth debate. Working Paper 10244, National Bureau of Economic Research, January 2004. URL http://www . nber .org/papers/w10244.

Laszla Halpern, Miklos Koren, and Adam Szeidl. Imported inputs and productivity. American Economic Review, 105(12):3660-3703, December 2015. doi: 10.1257/aer.20150443. URL http: //www. aeaweb.org/articles?id=10.1257/aer. 20150443.

Thomas J. Holmes. The Effects of Third-Degree Price Discrimination in Oligopoly. The American Economic Review, 79(1):244-250, March 1989.

Thomas J. Holmes and Ethan Singer. Indivisibilities in Distribution. NBER Working Papers 24525, National Bureau of Economic Research, Inc, April 2018.

David Hummels. Transportation costs and international trade in the second era of globalization. Journal of Economic Perspectives, 21(3):131-154, September 2007. doi: 10.1257/jep.21.3.131.

David Hummels and Peter Klenow. The Variety and Quality of a Nation's Exports. The American Economic Review, 95:704-723, 2005.

David Hummels, Volodymyr Lugovskyy, and Alexandre Skiba. The trade reducing effects of market power in international shipping. Journal of Development Economics, 89(1):84-97, May 2009.

David L. Hummels and Georg Schaur. Hedging price volatility using fast transport. Journal of International Economics, 82(1):15-25, September 2010.

David L. Hummels and Alexandre Skiba. Shipping the good apples out? an empirical confirmation of the alchian-allen conjecture. Journal of Political Economy, 112(6):1384-1402, 122004.

Anna Ignatenko. Price Discrimination in International Transportation: Evidence and Implications. Mimeo, UC Davis, 2019.

Alfonso Irarrazabal, Andreas Moxnes, and Luca David Opromolla. The Tip of the Iceberg: A Quantitative Framework for Estimating Trade Costs. The Review of Economics and Statistics, 97(4):777-792, 2015.

Jota Ishikawa and Nori Tarui. Backfiring with backhaul problems. Journal of International Economics, 111(C):81-98, 2018. doi: 10.1016/j.jinteco.2017.12. URL https://ideas.repec. org/a/eee/inecon/v111y2018icp81-98.html.

Robert Jensen. The Digital Provide: Information (Technology), Market Performance, and Welfare in the South Indian Fisheries Sector. The Quarterly Journal of Economics, 122(3):879-924, 2007.

Hiroyuki Kasahara and Joel Rodrigue. Does the use of imported intermediates increase productivity? Plant-level evidence. Journal of Development Economics, 87(1):106-118, August 2008. URL https://ideas.repec.org/a/eee/deveco/v87y2008i1p106-118.html. 
Paul Krugman. Scale Economies, Product Differentiation, and the Pattern of Trade. American Economic Review, 70(5):950-959, December 1980.

Ahmad Lashkaripour. Weight-Based Quality Specialization. Mimeo, Indiana University, 2019.

Nuno Limao and Anthony J. Venables. Infrastructure, Geographical Disadvantage, Transport Costs, and Trade. The World Bank Economic Review, 15(3):451-479, October 2001.

Volodymyr Lugovskyy and Alexandre Skiba. How geography affects quality. Journal of Development Economics, 115(C):156-180, 2015.

Volodymyr Lugovskyy and Alexandre Skiba. Income Distribution, Internal Geography, and Gains from Trade. Manuscript, 2019.

Marc J. Melitz. The Impact of Trade on Intra-Industry Reallocations and Aggregate Industry Productivity. Econometrica, 71(6):1695-1725, November 2003.

Paul Milgrom. Putting Auction Theory to Work. Cambridge University Press, 2004. URL https: //EconPapers.repec.org/RePEc: cup:cbooks: 9780521536721.

Monica Morlacco. Market Power in Input Markets: Theory and Evidence from French Manufacturing. Mimeo, University of Southern California, November 2019.

Horst Raff and Nicolas Schmitt. Buyer power in international markets. Journal of International Economics, 79(2):222-229, November 2009. URL https://ideas.repec.org/a/eee/inecon/ v79y2009i2p222-229.html.

Natalia Ramondo, AndrÃ@cs RodrÃguez-Clare, and Milagro SaborÃo-RodrÃguez. Trade, Domestic Frictions, and Scale Effects. American Economic Review, 106(10):3159-84, October 2016. doi: 10.1257/aer.20141449. URL http://www . aeaweb.org/articles?id=10.1257/aer.20141449.

James E. Rauch and Joel Watson. Starting small in an unfamiliar environment. International Journal of Industrial Organization, 21(7):1021-1042, September 2003.

Michael Reksulak and William Shughart. Of Rebates and Drawbacks: The Standard Oil (N.J.) Company and the Railroads. Review of Industrial Organization, 38(3):267-283, May 2011. doi: 10.1007/s11151-011-9279-7. URL https://ideas.repec.org/a/kap/revind/ v38y2011i3p267-283.html.

R. Schmalensee and R. Willig, editors. Handbook of Industrial Organization, volume 2 of Handbook of Industrial Organization. Elsevier, 1989. URL https://ideas.repec.org/b/eee/indhes/2. html.

Peter K. Schott. Across-Product versus Within-Product Specialization in International Trade. Quarterly Journal of Economics, 123:489-530, 2004.

Joanna Stavins. Price Discrimination in the Airline Market: The Effect of Market Concentration. The Review of Economics and Statistics, 83(1):200-202, February 2001. URL https://ideas . repec.org/a/tpr/restat/v83y2001i1p200-202.html. 
Lars A. Stole. Price Discrimination and Competition, volume 3 of Handbook of Industrial Organization, chapter 34, pages 2221-2299. Elsevier, 2007. URL https://ideas.repec.org/h/ eee/indchp/3-34.html.

Abiy Teshome. Property rights and hold-up in international shipping. Technical report, University of Virginia, 2018.

Petia Topalova and Amit Khandelwal. Trade Liberalization and Firm Productivity: The Case of India. The Review of Economics and Statistics, 93(3):995-1009, August 2011. URL https: //ideas.repec.org/a/tpr/restat/v93y2011i3p995-1009.html.

Woan Foong Wong. The Round Trip Effect: Endogenous Transport Costs and International Trade. Technical report, University of Oregon, 2018. 


\section{Appendix}

Table 8: The effect of firm's import size on the specific freight rate - Various definitions of firm import size, 2007-2009.

\begin{tabular}{l|ccc|ccc}
\hline \hline & \multicolumn{3}{|c}{ All Ports } & \multicolumn{3}{c}{ Only Identified Ports } \\
\hline$X:$ & Route & Total & Lagged & Route & Total & Lagged \\
\hline $\log ($ Price) & $0.52^{* *}$ & $0.54^{* *}$ & $0.58^{*}$ & $0.39^{* *}$ & $0.41^{* *}$ & $0.42^{*}$ \\
& $(0.24)$ & $(0.26)$ & $(0.30)$ & $(0.19)$ & $(0.21)$ & $(0.24)$ \\
$\log$ (Shipment value) & $-0.13^{* * *}$ & $-0.18^{* * *}$ & $-0.16^{* * *}$ & $-0.15^{* * *}$ & $-0.21^{* * *}$ & $-0.18^{* * *}$ \\
& $(0.04)$ & $(0.05)$ & $(0.04)$ & $(0.04)$ & $(0.05)$ & $(0.04)$ \\
$\log ($ Firm's $X$ import value) & $-0.03^{* * *}$ & $-0.03^{* * *}$ & $-0.04^{* * *}$ & $-0.03^{* * *}$ & $-0.02^{* *}$ & $-0.03^{* * *}$ \\
excludes current shipment) & $(0.01)$ & $(0.01)$ & $(0.01)$ & $(0.01)$ & $(0.01)$ & $(0.01)$ \\
Log(Weight/unit) & $0.50^{* *}$ & $0.49^{* *}$ & 0.45 & $0.62^{* * *}$ & $0.61^{* * *}$ & $0.60^{* * *}$ \\
& $(0.22)$ & $(0.23)$ & $(0.28)$ & $(0.18)$ & $(0.19)$ & $(0.22)$ \\
\hline Under-identification test & 4.86 & 4.91 & 4.58 & 4.14 & 4.18 & 3.98 \\
Under-identification p-value & 0.03 & 0.03 & 0.03 & 0.04 & 0.04 & 0.05 \\
Weak identification test & 39.55 & 42.11 & 41.91 & 46.71 & 47.65 & 48.11 \\
No. Routes & 260 & 260 & 234 & 177 & 177 & 164 \\
No. Obs & 482,873 & 482,873 & 278,764 & 350,435 & 350,435 & 208,960 \\
\hline \hline
\end{tabular}

Notes: IV regressions. Standard errors are clustered by route and country of origin. All variables are mean-differenced by product, route, year and month and we also include shipper fixed effects. *, **, *** significant at 10,5 , and 1 percent, respectively. In Columns (1) and (4), we define firm size as the annual imports of the firm on a port-to-port route. In column (2) and (5), we define the firm size as the total annual imports of the firm on all routes. In Columns (3) and (6), we define the firm size as the one-year lag total imports of the firm on all routes.

Table 9: The negative effect of firm's annual imports on the specific freight rate (including bulk and non-bulk commodities), 2007-2009.

\begin{tabular}{l|cc}
\hline \hline & All Ports & Only Identified Ports \\
\hline Log(Price) & $0.54^{* *}$ & $0.41^{* *}$ \\
& $(0.26)$ & $(0.21)$ \\
$\log ($ Shipment value) & $-0.13^{* * *}$ & $-0.16^{* * *}$ \\
& $(0.04)$ & $(0.04)$ \\
Log(Firm's imports) & $-0.03^{* * *}$ & $-0.03^{* * *}$ \\
(excludes current shipment) & $(0.01)$ & $(0.01)$ \\
Log(Weight/unit) & $0.48^{* *}$ & $0.60^{* * *}$ \\
& $(0.24)$ & $(0.19)$ \\
\hline Under-identification test & 4.90 & 4.15 \\
Under-identification p-value & 0.03 & 0.04 \\
Weak identification test & 41.49 & 48.24 \\
No. Routes & 260 & 177 \\
No. Obs & 522,917 & 378,282 \\
\hline \hline
\end{tabular}

Notes: IV regressions. Standard errors are clustered by route and country of origin. All variables are mean-differenced by product, route, year and month and we also include shipper fixed effects. *, **, *** significant at 10, 5 , and 1 percent, respectively. 
Table 10: The negative effect of firm's annual imports on the specific freight rate 2014-2015.

\begin{tabular}{|c|c|c|c|}
\hline \multirow{2}{*}{ Log(Price) } & \multicolumn{3}{|c|}{ Only Identified Ports } \\
\hline & $\begin{array}{c}0.29 \\
(0.44)\end{array}$ & $\begin{array}{c}0.29 \\
(0.44)\end{array}$ & $\begin{array}{c}0.29 \\
(0.44)\end{array}$ \\
\hline Log(Shipment value) & $\begin{array}{c}-0.19^{* * *} \\
(0.07)\end{array}$ & $\begin{array}{c}-0.18^{* * *} \\
(0.07)\end{array}$ & $\begin{array}{c}-0.18^{* * *} \\
(0.07)\end{array}$ \\
\hline Log(Firm's import value) & $-0.01^{* * *}$ & $-0.01^{* * *}$ & $-0.01^{* *}$ \\
\hline (excludes current shipment) & $(0.00)$ & $(0.00)$ & $(0.00)$ \\
\hline Imp Dummy & & $\begin{array}{c}0.07^{* * *} \\
(0.02)\end{array}$ & $\begin{array}{c}0.20^{* * *} \\
(0.05)\end{array}$ \\
\hline $\begin{array}{l}\text { Log(Firm's import value)*ImpDummy } \\
\text { (excludes current shipment) }\end{array}$ & & & $\begin{array}{c}-0.01^{* *} \\
(0.00)\end{array}$ \\
\hline Log(Weight/unit) & $\begin{array}{l}0.70^{*} \\
(0.41)\end{array}$ & $\begin{array}{l}0.70^{*} \\
(0.41)\end{array}$ & $\begin{array}{l}0.72^{*} \\
(0.42)\end{array}$ \\
\hline Under-identification test & 4.64 & 4.66 & 4.65 \\
\hline Under-identification p-value & 0.03 & 0.03 & 0.03 \\
\hline Weak identification test & 18.85 & 19.17 & 19.16 \\
\hline No. Routes & 176 & 176 & 176 \\
\hline No. Obs & 203,145 & 203,145 & 203,145 \\
\hline
\end{tabular}

Notes: IV regressions. Standard errors are clustered by route and country of origin. All variables are mean-differenced by product, route, year and month and we also include shipper fixed effects. *, **, *** significant at 10,5 , and 1 percent, respectively. ImpDummy equal 1 if the Chilean importing firm arranges transportation of the imported goods (using the Incoterms information in the data), 0 otherwise.

Table 11: The negative effect of firm's annual imports on the specific freight rate - more routes (with more than 5 firms per route).

\begin{tabular}{l|cc|cc}
\hline \hline & \multicolumn{2}{|c}{ All Ports } & \multicolumn{2}{c}{ Only Identified Ports } \\
\hline Imports measured by: & Value & Weight & Value & Weight \\
\hline Log(Price) & $0.52^{* *}$ & 0.42 & $0.40^{* *}$ & 0.24 \\
& $(0.25)$ & $(0.27)$ & $(0.20)$ & $(0.24)$ \\
$\log$ (Shipment value) & $-0.14^{* * *}$ & -0.06 & $-0.17^{* * *}$ & $-0.14^{*}$ \\
& $(0.05)$ & $(0.09)$ & $(0.05)$ & $(0.08)$ \\
Log(Firm's imports) & $-0.03^{* * *}$ & $-0.04^{* * *}$ & $-0.03^{* * *}$ & $-0.04^{* * *}$ \\
(excludes current shipment) & $(0.01)$ & $(0.01)$ & $(0.01)$ & $(0.01)$ \\
Log(Weight/unit) & $0.50^{* *}$ & $0.59^{* *}$ & $0.62^{* * *}$ & $0.77^{* * *}$ \\
& $(0.23)$ & $(0.27)$ & $(0.18)$ & $(0.24)$ \\
\hline Under-identification test & 4.90 & 5.05 & 4.16 & 4.30 \\
Under-identification p-value & 0.03 & 0.02 & 0.04 & 0.04 \\
Weak identification test & 40.96 & 19.13 & 47.53 & 16.55 \\
No. Routes & 356 & 356 & 235 & 235 \\
No. Obs & 487,293 & 487,293 & 353,935 & 353,935 \\
\hline \hline
\end{tabular}

Notes: IV regressions. Standard errors are clustered by route and country of origin. All variables are mean-differenced by product, route, year and month and we also include shipper fixed effects. *, **, *** significant at 10,5 , and 1 percent, respectively. 


\section{Technical Appendix: Cleaning the Identities of Shippers}

Utilizing the information on the identity of shippers delivering Chilean and Colombian imports is a critical part of our empirical exercise. Unfortunately, the names of shippers in neither Chilean nor Colombian Imports datasets are standardized. As a result, there are instances when the same firm is recorded differently due to using or not using abbreviations, capital and lower-case letters, spaces, dots, other special characters.

Table 12: The effect of firm's annual imports on the specific freight rate, OLS Regressions, 20072009.

\begin{tabular}{l|cc}
\hline \hline & All Ports & Only Identified Ports \\
\hline Log(Price) & $0.50^{* * *}$ & $0.51^{* * *}$ \\
& $(0.01)$ & $(0.02)$ \\
$\log ($ Shipment value) & $-0.08^{* * *}$ & $-0.09^{* * *}$ \\
& $(0.01)$ & $(0.01)$ \\
Log(Firm's imports) & $-0.03^{* * *}$ & $-0.03^{* * *}$ \\
(excludes current shipment) & $(0.00)$ & $(0.00)$ \\
Log(Weight/unit) & $0.51^{* * *}$ & $0.51^{* * *}$ \\
& $(0.02)$ & $(0.02)$ \\
Constant & $-0.00^{*}$ & $-0.00^{* * *}$ \\
& $(0.00)$ & $(0.00)$ \\
\hline Adj. R-squared & 0.59 & 0.60 \\
No. Routes & 260 & 177 \\
No. Obs & 506,589 & 366,922 \\
\hline \hline
\end{tabular}

Notes: Standard errors are clustered by route. All variables are mean-differenced by product, route, year and month and we also include shipper fixed effects. ${ }^{*}, * * * *$ significant at 10,5 , and 1 percent, respectively.

Table 13: The gap in specific freight rate paid by a large and a small firm

\begin{tabular}{l|ccc|ccc}
\hline \hline Annual Firm's Imports & \multicolumn{3}{|c}{$\hat{\alpha_{2}}=-0.03$} & \multicolumn{3}{c}{$\hat{\alpha_{2}}=-0.03, \hat{\alpha_{3}}=-0.16$} \\
\hline (measured in US dollars) & 2007 & 2008 & 2009 & 2007 & 2008 & 2009 \\
\hline 95 th/5th & $-16 \%$ & $-16 \%$ & $-15 \%$ & $-48 \%$ & $-49 \%$ & $-47 \%$ \\
90 th $/ 10$ th & $-13 \%$ & $-13 \%$ & $-12 \%$ & $-40 \%$ & $-41 \%$ & $-40 \%$ \\
80 th $/ 20$ th & $-9 \%$ & $-9 \%$ & $-8 \%$ & $-30 \%$ & $-28 \%$ & $-28 \%$ \\
75 th $/ 25$ th & $-7 \%$ & $-7 \%$ & $-7 \%$ & $-24 \%$ & $-25 \%$ & $-23 \%$ \\
95 th $/ 50$ th & $-10 \%$ & $-10 \%$ & $-10 \%$ & $-29 \%$ & $-32 \%$ & $-28 \%$ \\
50 th $/ 5$ th & $-6 \%$ & $-6 \%$ & $-6 \%$ & $-27 \%$ & $-25 \%$ & $-26 \%$ \\
\hline \hline
\end{tabular}

Notes: 1. Columns (1)-(3) present the specific freight rate paid by the firm with $x$ annual imports compared to the firm with $y$ annual imports is lower by $\left(1-\frac{x}{y} \hat{\alpha}_{2}\right) * 100 \%$, where $x>y$ and $\hat{\alpha_{2}}=-0.03$ from Table 4

2.Columns (4)-(6) present the specific freight rate paid by the firm with $x$ annual imports and $s_{x}$ average shipment value compared to the firm with $y$ annual imports and $s_{y}$ average shipment value is lower by $\left(1-\frac{x}{y} \hat{\alpha_{2}} * \frac{s_{x}}{s_{y}} \hat{\alpha_{3}}\right) * 100$ $\%$, where $x>y$ and $\hat{\alpha_{2}}=-0.03$ and $\hat{\alpha_{3}}=-0.16$ from Table 4 . 
Table 14: The gap in specific freight rate paid by a large and a small firm.

\begin{tabular}{l|ccc|ccc}
\hline \hline Annual Firm's Imports & \multicolumn{3}{|c}{$\hat{\alpha_{2}}=-0.04$} & \multicolumn{3}{c}{$\hat{\alpha_{2}}=-0.04, \hat{\alpha_{3}}=-0.14$} \\
\hline (measured in kilograms) & 2007 & 2008 & 2009 & 2007 & 2008 & 2009 \\
\hline 95th/5th & $-25 \%$ & $-25 \%$ & $-24 \%$ & $-61 \%$ & $-62 \%$ & $-61 \%$ \\
90 th/10th & $-20 \%$ & $-20 \%$ & $-20 \%$ & $-50 \%$ & $-52 \%$ & $-49 \%$ \\
80 th/20th & $-13 \%$ & $-13 \%$ & $-13 \%$ & $-37 \%$ & $-37 \%$ & $-37 \%$ \\
75 th/25th & $-11 \%$ & $-11 \%$ & $-11 \%$ & $-32 \%$ & $-31 \%$ & $-31 \%$ \\
95 th/50th & $-15 \%$ & $-15 \%$ & $-15 \%$ & $-35 \%$ & $-37 \%$ & $-36 \%$ \\
50 th/5th & $-16 \%$ & $-16 \%$ & $-15 \%$ & $-40 \%$ & $-40 \%$ & $-39 \%$ \\
\hline \hline
\end{tabular}

Notes: 1. Columns (1)-(3) present the specific freight rate paid by the firm with $x$ annual imports compared to the firm with $y$ annual imports is lower by $\left(1-\frac{x}{y} \hat{\alpha}_{2}\right) * 100 \%$, where $x>y$ and $\hat{\alpha_{2}}=-0.04$ from Table 4

2.Columns (4)-(6) present the specific freight rate paid by the firm with $x$ annual imports and $s_{x}$ average shipment value compared to the firm with $y$ annual imports and $s_{y}$ average shipment value is lower by $\left(1-\frac{x}{y}{\hat{\alpha_{2}}} * \frac{s_{x}}{s_{y}} \hat{\alpha_{3}}\right) * 100$ $\%$, where $x>y$ and $\hat{\alpha_{2}}=-0.04$ and $\hat{\alpha_{3}}=-0.14$ from Table 4 . 